\title{
Structural and seismic stratigraphic framework of the NanTroSEIZE Stage 1 transect $^{1}$
}

\author{
G.F. Moore, ${ }^{2}$ J.-O. Park, ${ }^{3,4}$ N.L. Bangs, ${ }^{5}$ S.P. Gulick, ${ }^{2}$ H.J. Tobin, ${ }^{2}{ }^{\text {Y. Nakamura, }}{ }^{2}$ S. Sato, ${ }^{3}$ T. Tsuji, ${ }^{6}$ \\ T. Yoro, ${ }^{7}$ H. Tanaka, ${ }^{7}$ S. Uraki, ${ }^{7}$ Y. Kido, ${ }^{7}$ Y. Sanada, ${ }^{7}$ S. Kuramoto, ${ }^{7}$ and A. Taira ${ }^{7}$
}

\section{Chapter contents}

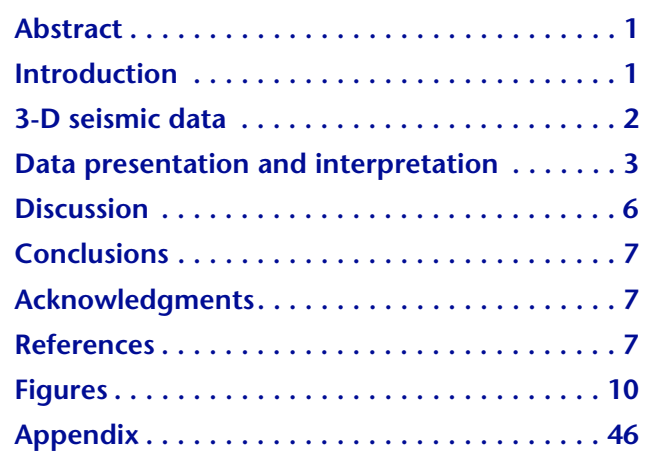

${ }^{1}$ Moore, G.F., Park, J.-O., Bangs, N.L., Gulick, S.P., Tobin, H.J., Nakamura, Y., Sato, S., Tsuji, T., Yoro, T., Tanaka, H., Uraki, S., Kido, Y., Sanada, Y., Kuramoto, S., and Taira, A., 2009. Structural and seismic stratigraphic framework of the NanTroSEIZE Stage 1 transect. In Kinoshita, M., Tobin, H., Ashi, J., Kimura, G., Lallemant, S., Screaton, E.J., Curewitz, D., Masago, H., Moe, K.T., and the Expedition 314/315/316 Scientists, Proc. IODP, 314/315/316: Washington, DC (Integrated Ocean Drilling Program Management International, Inc.). doi:10.2204/iodp.proc.314315316.102.2009 ${ }^{2}$ Expedition 314/315/316 Scientists' addresses. Correspondence author: gmoore@hawaii.edu ${ }^{3}$ Institute for Research on Earth Evolution/ JAMSTEC, 3173-25 Showa-machi, Kanazawa-ku, Yokohama, Kanagawa 236-0001, Japan. ${ }^{4}$ Ocean Research Institute, Tokyo University, Tokyo, Japan.

${ }^{5}$ University of Texas Institute for Geophysics, 10100 Burnet Road, Austin TX 78758-4445, USA. ${ }^{6}$ Department of Civil and Earth Resources Engineering, Kyoto University, Nishikyo-ku, Kyoto 615-8540, Japan.

${ }^{7}$ Center for Deep Earth Exploration/JAMSTEC, 3173-25 Showa-machi, Kanazawa-ku, Yokohama, Kanagawa 236-0001, Japan.

\section{Abstract}

The location of the Integrated Ocean Drilling Program's (IODP) Nankai Trough Seismogenic Zone Experiment (NanTroSEIZE) was based on regional two-dimensional seismic reflection surveys carried out by the Japan Agency for Marine-Earth Science and Technology (JAMSTEC). Final site locations were chosen based on a three-dimensional (3-D) seismic reflection survey acquired across the seaward margin of Kumano Basin and the accretionary prism from the basin to the deformation front. This survey covered a region $12 \mathrm{~km}$ wide (approximately parallel to the regional structural strike) and $56 \mathrm{~km}$ long (approximately perpendicular to the regional strike) and provided detailed images of the structure and seismic stratigraphy of the drill sites. Sites were drilled in the frontal thrust zone at the toe of the accretionary prism, the frontal region of the megasplay fault zone, and the forearc basin. The 3-D seismic data volume images a main frontal thrust at the prism toe with the hanging wall thrust at least $7.5 \mathrm{~km}$ seaward over the trench. This configuration is different from that in other parts of the Nankai prism. At the shallow end of the megasplay, the data images a complex thrust system that truncates older structures in the underlying accretionary prism and shows that the hanging wall block has overridden more than $1250 \mathrm{~m}$ of young slope sediments. At the forearc basin site, we interpret landward-dipping forearc basin strata onlapping older slope sediments, which in turn overlie an older part of the accretionary prism.

\section{Introduction}

The Nankai Trough, as the type example of a subduction zone accreting a thick terrigenous sediment section, has been a site of intense study, including Deep Sea Drilling Project (DSDP) and Ocean Drilling Program (ODP) drilling (Karig, Ingle, et al., 1975; Taira, Hill, Firth, et al., 1991; Moore et al., 2001), numerous twodimensional (2-D) and three-dimensional (3-D) seismic reflection surveys and ocean bottom seismometer wide-angle seismic surveys (e.g., Aoki et al., 1982; Moore et al., 1990; Park et al., 2002a; 2002b; Taira et al., 2005; Kodaira et al., 2006; Nakanishi et al., 2008), and heat flow and submersible surveys (e.g., Ashi et al., 2002). As part of a continuing multidisciplinary scientific investigation of seismogenic processes in the Nankai Trough, the Integrated Ocean Drilling Program (IODP) Nankai Trough Seismogenic Zone Experiment (NanTroSEIZE) is focused on a transect 
south of Kii Peninsula, Honshu, Japan (Fig. F1). Several 2-D seismic reflection data sets across the $\mathrm{Ku}$ mano Basin region of the Nankai Trough (Fig. F2) were used to define the regional tectonic setting and locate the NanTroSEIZE drilling transect, but these data sets lacked both adequate imaging to interpret the complex 3-D structure and the detail needed to prepare for the planned deep riser drilling. In order to better image this region for proper structural interpretation, choose final site locations, and characterize these locations for riser drilling, we carried out a commercial 3-D seismic survey, funded by Japanese (Ministry of Education, Sports, Culture, and Technology) and U.S. (National Science Foundation) sources. In this chapter we describe the acquisition and processing of this 3-D data set and present preliminary interpretations of the structure and seismic stratigraphy of the NanTroSEIZE drill sites based on all of the available regional bathymetric and 2-D and 3-D seismic data sets.

\section{Regional setting of the NanTroSEIZE transect}

The Philippine Sea plate (PSP) is being subducted beneath southwest Japan at the Nankai Trough subduction zone at a rate of $\sim 4-6.5 \mathrm{~cm} / \mathrm{y}$ at an azimuth of $\sim 300^{\circ}-315^{\circ}$ (Seno et al., 1993; Miyazaki and Heki, 2001; Zang et al., 2002). The northern margin of the PSP (Fig. F1), the Shikoku Basin, was formed by backarc spreading behind the Izu-Bonin arc system $~ 25-$ $15 \mathrm{Ma}$ (Okino et al., 1994). Late-stage reorientations of spreading in Shikoku Basin caused large variations in basement relief with associated variations in thickness and sediment type in overlying sedimentary sections (Ike et al., 2008b). For instance, Miocene turbidites filled deep basement grabens, but these turbidites only onlap adjacent basement highs; the basement highs are draped by thin hemipelagic sediment (Ike et al., 2008a). The Miocene and younger strata were designated the lower and upper Shikoku Basin facies at ODP Site 808 (Taira, Hill, Firth, et al., 1991). A trench sediment wedge $\sim 1.3 \mathrm{~km}$ thick overlies $\sim 1.1 \mathrm{~km}$ of Shikoku Basin deposits in the NanTroSEIZE transect area, where all of the trench deposits and at least half of the Shikoku Basin deposits are accreted to form a wide accretionary prism (Park et al., 2002a).

The Nankai Trough region has a long record of historic great earthquakes that have generated large tsunamis (Ando, 1975). The Kumano transect is within the region that ruptured during the 1944 and 1946 earthquakes (Baba and Cummins, 2005), and this portion of the seismogenic zone is the target of future NanTroSEIZE drilling (Tobin and Kinoshita, 2006).

\section{3-D seismic data}

\section{Acquisition}

We contracted with Petroleum Geo-Services (PGS) to acquire the 3-D survey with the M/V Nordic Explorer from April 2006 to May 2006. As the sound source, we deployed two arrays, each with 28 Sodera G-guns totaling $51 \mathrm{~L}\left(3090 \mathrm{in}^{3}\right)$, fired alternately at $37.5 \mathrm{~m}$ shot intervals. Modeling of the far-field signature of the G-gun arrays shows that the source was minimum phase with primary energy of 68.2 bar-m, peakpeak energy of 141.4 bar-m, and primary to bubble amplitude ratio of 86.7. The survey used four receiver cables spaced $150 \mathrm{~m}$ apart, each $4500 \mathrm{~m}$ long with 360 receiver groups at $12.5 \mathrm{~m}$ spacing (Fig. F3). This 4-streamer/2-source array geometry yielded 8 sourcereceiver common midpoint (CMP) lines per sail line at a spacing of $37.5 \mathrm{~m}$ and nominal 30 -fold data.

The resulting 3-D data set covers an $\sim 12 \mathrm{~km} \times 56 \mathrm{~km}$ area that extends from the Kumano Basin seaward to the frontal thrust in the dip direction and extends along strike $\sim 4 \mathrm{~km}$ northeast and $\sim 8 \mathrm{~km}$ southwest of the NanTroSEIZE drilling transect (Fig. F4). The long axis of the survey is oriented at $330.1^{\circ}$, and the total area of the survey was $\sim 585 \mathrm{~km}^{2}$. The inline direction is parallel to the long axis of the survey and the cross-line direction is parallel to the short axis $\left(60.1^{\circ}\right)$.

Navigation included a differential Global Positioning System (GPS; Fugro StarFix) for the survey vessel, with each G-gun array and tail buoy also having GPS receivers. A Sonardyne SIPS2 acoustic transponder array was deployed on the G-guns and streamers such that the location of each receiver was sensed and recorded for each shot. Onboard navigation processing was carried out using SPRINT software. Relative accuracy of the shot and receiver locations is estimated to be $\pm 5 \mathrm{~m}$.

Acquisition was made difficult by the Kuroshio Current, which had maximum velocities during the survey of 4-4.5 km from the west-southwest with the main axis approximately perpendicular to our survey direction. Neither the current's direction nor its magnitude were constant, so the feather angle of the streamers varied, thus making it impossible to perfectly match the offsets on adjacent passes, and therefore requiring significant additional passes to fill in gaps in data coverage. Turns at the southeast end of the survey were also complicated by the strong current, thus preventing most of the CMP lines from reaching the trench axis.

\section{Processing}

3-D seismic processing consisted of three stages. In the first stage, PGS provided a 3-D stack and post- 
stack migration, which gave a "quick look" at the 3-D data volume that was useful for understanding the regional seismic reflection characteristics for choosing parameters for more detailed processing.

During the second stage, the data set was processed through 3-D prestack time migration (PSTM) by Compagnie Générale de Géophysique (CGG) in Kuala Lumpur, Malaysia (see the "Appendix"). Because of the variable streamer feathering, several processing steps were necessary to fill and regularize all of the bins. Strong seafloor multiples also required several multiple attenuation steps in the premigration stage.

The third stage consisted of 3-D prestack depth migration (PSDM) performed at Japan Agency for Marine Earth Science and Technology (JAMSTEC)Institute for Research on Earth Evolution (IFREE). The final gathers that were preprocessed by CGG were used as input to the 3-D PSDM (see the "Appendix"). The 3-D PSDM clearly images details of faults and small-scale structures that were not easily recognized in the PSTM data set (Fig. F5). However, because of the length of the streamers $(4500 \mathrm{~m})$ and the strong feathering, velocity resolution deeper than $\sim 4500-5000 \mathrm{~m}$ is less accurate. Therefore, although imaging of the deeper section (i.e., the top of oceanic crust) is quite good, the depths are less accurate than in the shallow region.

\section{Resolution of the 3-D seismic data}

In order to conduct proper geologic interpretations of seismic reflection data, the resolution of the data must be known. Seismic resolution is generally defined in terms of the wavelength of the data (Sheriff, 1991):

$$
\text { Limit of resolution }=\lambda / 4=V / 4 f
$$

where

$$
\begin{aligned}
\lambda & =\text { wavelength } \\
V & =\text { velocity }, \text { and } \\
f & =\text { frequency. }
\end{aligned}
$$

For the near-surface sediments, $P$-wave velocity is generally $<1600-1800 \mathrm{~m} / \mathrm{s}$ and frequency content is $\sim 60-80 \mathrm{~Hz}$. At our maximum drilling depths of $\sim 1400 \mathrm{~m}$, velocities are $\sim 2400 \mathrm{~m} / \mathrm{s}$ and frequencies are $\sim 40 \mathrm{~Hz}$. For the deepest regions imaged by our data set, velocities increase to $>4000 \mathrm{~m} / \mathrm{s}$ and frequency decreases to $\sim 8 \mathrm{~Hz}$. These values yield the following results:

1. $\lambda / 4=(1600-1900 \mathrm{~m} / \mathrm{s}) / 4 \times(80-60 \mathrm{~Hz}) \sim 5-7 \mathrm{~m}$ for near-surface sediments,

2. $\lambda / 4=(2000-2400 \mathrm{~m} / \mathrm{s}) / 4 \times(50-30 \mathrm{~Hz}) \sim 10-20 \mathrm{~m}$ for the deepest sediments drilled, and
3. $\lambda / 4=(3600-4000 \mathrm{~m} / \mathrm{s}) / 4 \times(10-8 \mathrm{~Hz}) \sim 90-125 \mathrm{~m}$ for the oceanic crust region.

\section{Data presentation and interpretation}

\author{
Regional perspective
}

We used the regional 2-D seismic reflection lines to identify key tectonic features of the Nankai accretionary prism in the Kumano transect. We then extrapolated these features laterally using a highresolution multibeam bathymetric data set (Fig. F4A) to produce a preliminary regional tectonic interpretation (Fig. F4B). We note that all interpretations should be considered preliminary because additional interpretation work is ongoing.

A composite seismic line extracted from the 3-D volume that crosses over (or close to) Stage 1 drill sites (location shown in Figs. F2 and F4B) illustrates the main regional morphotectonic zones and seismic features of the drilling transect (Fig. F6). The reflection from the top of ocean crust is imaged from the Nankai Trough in the southeast landward to a depth of $\sim 11 \mathrm{~km}$ under the center of Kumano Basin. As mentioned above, potential velocity errors in the deep part of the section preclude accurate interpretation of oceanic crustal structure. Several basement highs, however, are apparent that we believe to be real, including the ridge above the interpreted landward-dipping thrust fault within the oceanic crust landward of the trench axis (Tsuji et al., in press). Above the irregular oceanic crust reflection is a seismically transparent unit that we interpret to be hemipelagic sediment of the Shikoku Basin facies (Moore et al., 2001) that is subducting with the oceanic crust. This unit can be traced landward at least $45 \mathrm{~km}$ under the Kumano Basin with little change in thickness (Fig. F6).

In the trench zone, younger trench deposits overlie the oceanic crust and Shikoku Basin facies (Fig. F6). As is typical of other parts of the Nankai Trough, there is a well-developed protothrust zone (PTZ), but the PTZ is overlain by a slice of trench strata previously accreted into the prism and emplaced over the trench strata by an out-of-sequence thrust (OOST). The frontal thrust zone is highly complex with a very steep slope $\left(\sim 10^{\circ}\right)$ at the seaward edge of the prism. Landward of the trench is the imbricate thrust zone (ITZ), a series of thrust packages made up of a thick highly reflective sequence that is probably accreted trench sediment. The primary thrusts that extend through the accretionary wedge and sole into the basal décollement are highly irregular with 1.5$2.5 \mathrm{~km}$ downdip spacing and typical along-strike extents of $\sim 1-3 \mathrm{~km}$. These faults are recognizable by 
the displacement of the deformed stratigraphic horizons that comprise the accretionary wedge. The décollement is a strong continuous positive polarity reflection through most of the frontal region. A potential inactive décollement occurs $\sim 500 \mathrm{~m}$ above the active décollement in a zone of low-velocity material that may be underplated hemipelagic material (Park et al., in press).

The ITZ is overlain by slope sediments that are increasingly deformed downward. The slope sediment cover generally increases in thickness from southeast to northwest (Fig. F6). Recent tectonic activity is reflected in numerous surficial landslide scars and by two apparent strike-slip faults that offset young ridges in the ITZ (Fig. F4B).

Beneath the trench upper slope and Kumano Basin, a regional OOST or splay fault system, first recognized by Park et al. (2002a), cuts across the older part of the accretionary prism in the megasplay fault zone. The megasplay fault can be traced from deep below the accretionary wedge at $\sim 10 \mathrm{~km}$ depth, where it lies $\sim 1 \mathrm{~km}$ above the top of the subducting crust. It cuts discontinuously up through the accretionary wedge along several branches all the way to the frontal accretionary thrust region (Moore et al., 2007). Deep segments of the splay fault are continuous along strike across the entire $12 \mathrm{~km}$ survey width, with shallower segments continuing typically $3-5 \mathrm{~km}$ along strike. Many segments along the splay fault system have reversed polarity reflections relative to the seafloor and high amplitudes relative to adjacent stratigraphic horizons. The fault segments are potentially active fluid conduits fed by deep sources, possibly including the thick underthrust sediment package (Bangs et al., in press).

The Kumano forearc basin is bounded on the southeast by a topographic valley. Beneath the valley is a complex fault zone that may have a combination of normal and strike-slip faults (Kumano Basin edge fault zone; Martin et al., 2007, 2008).

More than $2 \mathrm{~km}$ of sediment is imaged in the $\mathrm{Ku}$ mano forearc basin. The seaward portion of the basin section is progressively tilted, likely because of repeated motion on the megasplay fault (Park et al., 2002a), and is cut by landward-dipping normal faults (Gulick et al., 2008). The region below the base of the Kumano Basin sediments is generally reflection free and is probably older accreted material.

\section{Detailed views around NanTroSEIZE drill sites}

\section{Toe of accretionary prism: IODP Sites C0006 and $\mathrm{C} 0007$}

Sites $\mathrm{C0006}$ and $\mathrm{C0007}$ are located on the first ridge landward of the frontal thrust (Fig. F7). Seismic In- line 2434 shows the setting of these sites (Figs. F8, F9).

The sedimentary section in the trench region is $\sim 2.4 \mathrm{~km}$ thick (Fig. F8) and is typical of the Nankai Trough, with Shikoku Basin hemipelagics and turbidites $(\sim 1.4 \mathrm{~km})$ overlying oceanic crust and subsequently overlain by a trench sediment wedge $(\sim 1 \mathrm{~km})$. The trench wedge has numerous nested trench channels, and this complex of channels extends under the toe of the accretionary prism.

A well-developed PTZ affects the upper Shikoku Basin and lower trench wedge sections (Figs. F8, F9). The steeply landward-dipping thrusts have small offsets and extend from approximately the base of the trench channel complex to a strong reflection at $\sim 6 \mathrm{~km}$ depth near the base of the interpreted trench wedge. We note that the landward-dipping reflections in the Shikoku Basin sequences are likely migration noise due to very low fold in this region.

The frontal thrust is a shallow-dipping $\left(\sim 7^{\circ}-8^{\circ}\right)$ detachment that extends landward $\sim 6 \mathrm{~km}$ and displaces trench and upper Shikoku Basin facies over the PTZ and younger trench sediments (Figs. F8, F9). At its seaward edge, the frontal thrust is essentially parallel to bedding in both the hanging wall and footwall.

The detailed bathymetry of the trench axis and lowermost accretionary prism (Fig. F7) shows that Sites C0006 and C0007 are on the northeast flank of a large landslide scar. Debris from this landslide form a thick, irregular deposit at the base of the scar and have caused the trench axial channel to be deflected at least $10 \mathrm{~km}$ seaward from its usual position at the base of the landward slope.

The region around Sites C0006 and C0007 is dominated by steep landward-dipping subsidiary thrust faults that steepen with depth. Most offsets are less than a few tens of meters, except the fault penetrated at $4200 \mathrm{~m}$ at Site C0006 (Fig. F9). Northwest of Site C0006 a series of backthrusts cuts the section. Further landward of these backthrusts two additional landward-dipping subsidiary thrusts cut the section, and both sole into the main frontal thrust.

A small slope basin formed landward of Site C0006 from debris shed off the steep landward slope. Sediments in the wedge-shaped basin onlap the underlying accreted trench strata (Fig. F9).

The thrust block landward of the slope basin has been translated seaward at least $1.25 \mathrm{~km}$ over the basin sediments. Also, the thrust beneath this block has cut off the top of an underlying anticline (Fig. F8, Cross-line 3750), further indicating that the thrust is younger than the underlying thrust and slope sediments, making it an OOST. The surface 
slope of the overriding thrust block (Cross-line $3650-4000)$ is relatively steep $\left(\sim 10^{\circ}\right.$ seaward slope) compared to the average surface slope of the region just landward $\left(\sim 3^{\circ}\right)$. The overriding block is cut by at least two subsidiary thrusts that splay off the main thrust. The block exhibits very low seismic amplitudes with little continuity and is distinct from the footwall block. Low seismic amplitudes often indicate distinctive lithologic units, small-scale deformation, or steep dips, as discussed further below.

\section{Seaward edge of splay fault system: IODP Sites C0001, C0003, C0004, and C0008}

These sites are all on the seaward slope of the accretionary prism, just southeast of a major ridge that forms part of the seaward boundary of Kumano Basin (Fig. F10). Two seismic inlines (Figs. F11, F12) show the setting of these sites at the seaward edge of the megasplay system. A series of thrusts within the accretionary prism offset bands of high-amplitude laterally continuous reflections interpreted as accreted trench and Shikoku Basin strata (Park et al., 2002a; Kington et al., 2008; Streiff et al., 2008). The strata are folded into hanging wall anticlines over the thrusts (Moore et al., 2007). The seismic crosslines (Fig. F13) show that the thrusts are not perpendicular to the strike of the margin but dip at an oblique angle, thus causing oblique ramps to form. The megasplay cuts the top of these oblique ramps, providing compelling evidence for the out-ofsequence nature of the megasplay (Moore et al., 2007).

The overthrusting block, penetrated at Sites C0001, C0003, and C0004, is characterized by low seismic amplitudes and the lack of laterally continuous seismic reflections similar to the overthrust block in the toe region described above. Several low-amplitude landward-dipping reflections are interpreted as thrusts within this block that is believed to be older accreted material brought up from depth along the megasplay fault (Moore et al., 2007). Two higher amplitude zones, also interpreted as thrusts, were penetrated at Site C0003. At Site C0001, low-amplitude seaward-dipping reflections dominate (Figs. F14, F15). We interpret these reflections as backthrusts because of their dips (nearly perpendicular to the thrusts) and because a package of prominent landwarddipping reflections is cut off by one of these reflections (Fig. F14, Cross-line 5540-5560).

The megasplay surface is not a simple planar fault but is a complex series of anastomosing segments (Figs. F16, F17). Both amplitudes and geometries of the fault segments change rapidly along strike and downdip. At Site C0004, it is a zone $\sim 100 \mathrm{~m}$ thick with reflections at the top and base (Fig. F17).
The top of the megasplay block is highly irregular in three dimensions. We believe that most of this roughness is due to slumping of material from the top of the block, a process that continues today on thrust anticlines on the lower portion of the prism slope.

The megasplay block has overridden younger slope sediments (Fig. F16) that extend at least $1250 \mathrm{~m}$ landward under the block. These sediments were penetrated at Sites C0004 and C0008. The block is also overlain by the youngest slope sediments, which were sampled at Sites C0001 and C0004.

The slope sediment cover is cut by numerous smalloffset normal faults (Fig. F18). Although the faults are imaged in the 3-D inlines (e.g., Fig. F16, Crossline $\sim 5190-5200,3.0 \mathrm{~km}$ ), they dip approximately parallel to the inlines, so they are best displayed in the cross-lines (Fig. F17, F18). In addition, two northwest-striking strike-slip faults offset surface ridges in the ITZ (Fig. F4) and truncate reflection horizons within the 3-D data volume.

The slope sediments are also affected by slumping. Many slump scars are visible in the regional bathymetry (Fig. F4A) and on the 3-D seismic lines (e.g., Figs. F16, F17), and regional onlap surfaces within the slope sediments occur in several places (Figs. F14, F15, F16, F19).

\section{Kumano forearc basin: IODP Site C0002}

Site C0002 is located near the seaward (southeast) edge of the Kumano forearc basin (Fig. F20). A seismic inline imaging the drill site (Fig. F21) shows $\sim 900 \mathrm{~m}$ of landward (northwest)-tilted, high-amplitude, laterally continuous reflections that we interpret as a turbidite sequence (Gulick et al., 2008). The turbidites lap onto an older sequence $\sim 50-100 \mathrm{~m}$ thick that is relatively transparent with lateral thickness variations. We interpret this sequence to be hemipelagic sediments deposited on the lower trench slope prior to formation of the forearc basin.

Underlying the sedimentary sequence is a strongly deformed zone that has few laterally continuous seismic reflections. Landward of Site C0002 (Cross-line $\sim 6230-6330$ ) is an anticline that we interpret to be the top of a hanging wall structure similar to those imaged in the accretionary prism to the southeast. These strata may have been deposited in a slope basin environment and then uplifted to form the base of the forearc basin (Gulick et al., 2008).

The forearc basin sequence is cut by a series of landward (northwest)-dipping normal faults (Gulick et al., 2008). We cannot identify any depth variations in offsets along these faults that would indicate that they are growth structures. Many of the faults extend 
to the surface and some cut the entire basin sequence into the underlying prism. Several normal faults are also imaged in the cross-line direction (Fig. F22), indicating that their strikes are oblique to the trend of the margin (see the "Expedition 314 Site C0002" chapter).

The seismic cross-line through Site C0002 shows that surface sediments in the basin are affected by slumping with large slump scars evident northeast and southwest of Site C0002. These slump scars are also evident in the regional bathymetry (Figs. F4A, F20).

A strong bottom-simulating reflector (BSR) occurs throughout Kumano Basin (G. Gaillot et al., unpubl. data). This high-amplitude negative polarity BSR is strongest to the southeast of Site $\mathrm{C0002}$ and has minimal amplitude at the site.

\section{Discussion}

\section{Frontal thrust zone}

The frontal thrust region in the Kumano transect is highly anomalous compared to the Nankai prism west of this transect (Okino and Kato, 1995; Kimura et al., 2007) where the frontal thrust marks the landward boundary of the PTZ, dips landward at $\sim 25^{\circ}-$ $35^{\circ}$, and extends only 1-2 km landward (e.g., Aoki et al., 1982; Moore et al., 1990; Gulick et al., 2004). In the Kumano transect, however, the frontal thrust is a shallow-dipping $\left(<10^{\circ}\right)$ detachment that extends landward $\sim 6 \mathrm{~km}$ and displaces trench and upper Shikoku Basin facies over the deeper PTZ and younger trench sediments (Figs. F8, F9). At its seaward edge, the frontal thrust is essentially parallel to bedding in both the hanging wall and footwall, denoting a classic "flat on flat" overthrust geometry, in contrast to the "ramp on ramp" geometry observed along most of the Nankai Trough.

Another anomalous feature of the Kumano transect frontal thrust zone is the development of an OOST $<5 \mathrm{~km}$ landward of the frontal thrust. The lack of seismic continuity in the overthrust block may indicate that the block has been thrust up from deeper within the prism with seismic reflections being disrupted by microfracturing as the release of pressure allows fractures within the block to open.

We identified a large landslide just west of the 3-D box (Fig. F4B). This landslide was probably caused by the subduction of a small seamount imaged in a nearby 2-D line (ODKM03-I, Taira et al., 2005). This topography is typical of landslides caused by seamount subduction in other convergent margins (e.g., Dominguez et al., 2000).The large embayment in the seafloor just west of the 3-D box is likely the result of recent subduction of a ridge or seamount with resulting collapse as it passed under the frontal ridge (e.g., Lallemand and Le Pichon, 1987; Park et al., 1999; Dominguez et al., 2000). A likely phenomenon associated with this ridge or seamount is a significantly thicker sedimentary section at the trailing margin of the topographic feature (Ike et al., 2008a, $2008 b$ ). It is likely that the combination of ridge/ seamount subduction with thin sediments on the landward flank of the feature and thick sediments on the seaward flank has greatly altered the "normal" structural regime at the toe of the prism.

\section{Frontal prism}

The frontal prism is formed of accreted trench turbidites and underlying Shikoku Basin hemipelagic deposits. We identified lateral or oblique thrust ramps in this region, indicating that thrust motion is at an oblique angle to the strike of the thrusts. The ramp anticlines, although blanketed with slope sediments in the mid-slope region, form a series of ridges and troughs whose trend defines the strike of the oblique ramps. This topographic trend dominates the region from the frontal ridge landward to the splay fault. Both the frontal ridge and the splay fault cut off the oblique ramp trends, perhaps reflecting a recent change in the regional stress pattern.

\section{Megasplay}

Displacement along the megasplay is at least $1250 \mathrm{~m}$ in the horizontal direction and at least $750 \mathrm{~m}$ in the vertical direction (as indicated by the amount of slope sediment overridden), so the minimum displacement along the thrust is $1450 \mathrm{~m}$. As opposed to the underlying accretionary prism thrusts, there is no indication of lateral slip along the megasplay, so our inlines, oriented approximately parallel to the direction of slip, should provide an accurate representation of splay fault slip.

\section{Normal faulting seaward of megasplay thrust}

Many shallow normal faults cut the slope sediments in the frontal splay fault region. These faults are best observed on the seismic cross-lines over Sites C0004 and C0008 (Figs. F17, F18). The faults generally strike $\sim 290^{\circ}-310^{\circ}$ approximately perpendicular to the overall trend of the prism with steep dips to both the northeast and southwest. These normal faults may be due to extension as the underlying prism blocks ride up the underlying lateral ramps.

\section{Kumano forearc basin}

Above the splay fault under Kumano Basin is a unit that consists of steeply dipping discontinuous reflec- 
tions that we interpret to be an older part of the accretionary prism. There are many indications that the older prism is similar to the current frontal prism, such as the structure on Figure F21 between Cross-lines 6240 and 6340, which we interpret to be the top of a hanging wall anticline. There are also several segments of landward-dipping reflections within the old prism.

Overlying the older prism is a hemipelagic unit that in some places has seaward dips and in other areas fills topographic lows in the underlying prism. We interpret this unit to be slope sediments that filled in small basins on the lower trench slope before this part of the prism was uplifted by slip along the splay fault.

The slope sediment sequence is onlapped by a thick succession of turbidite sediments that are tilted landward, presumably because of uplift at the seaward flank of the basin by slip along the megasplay (Park et al., 2002a; Gulick et al., 2008). This uplift has shifted the present locus of sedimentation landward in the basin. The basin sediments are cut by normal faults, many of which cut the surface sediment. The faults show no evidence for differential offset with depth. We thus believe that most of the faulting is very young.

\section{Conclusions}

Our 3-D seismic reflection data set images several key features of the NanTroSEIZE Kumano transect that are relevant to the drilling results reported in this volume:

- The frontal thrust region is anomalous compared to other parts of the Nankai Trough in that the thrust is a shallow-dipping detachment that extends $>10 \mathrm{~km}$ landward, whereas the frontal thrusts in other parts of the Nankai prism dip $\sim 30^{\circ}$ and extend no more than $1 \mathrm{~km}$ landward. Near the toe of the prism is an OOST that has recently overridden the frontal block.

- At the frontal part of the megasplay system, our 3-D data show that the underlying accretionary prism thrusts have oblique slip that generated lateral (or oblique) ramp hanging wall anticlines. The oblique ramp structures have been truncated by the megasplay, which has overridden at least $1250 \mathrm{~m}$ of young slope sediments. The tip of the megasplay fault is a complex anastomosing series of thrusts that strongly deform the underlying slope sediments. Northwest-striking normal faults cut the slope sediment section beneath and in front of the megasplay fault.

Key interpretations of seismic reflection data across the forearc basin are (1) landward tilting of the basin section, (2) hemipelagic strata below the main basin fill that drape an older unit and are interpreted to be slope/slope basin strata, and (3) older accretionary prism material below the forearc/slope sediments.

\section{Acknowledgments}

Funding for this project was provided in part by the Ministry of Education, Sports, Culture, and Technology (MEXT) in Japan and the U.S. National Science Foundation (NSF) via grants OCE-0451790 (UH), OCE-0452340 (UT), and OCE-0800653 (UW). The authors would like to thank the officers, crew, and technical staff of the PGS vessel Nordic Explorer for collecting excellent quality data under difficult circumstances and the processing group at CGG in Kuala Lumpur for producing an excellent PSTM product. A review by Juli Morgan clarified many parts of the final draft. We thank Paradigm for providing the GeoDepth software used for the 3-D PSDM. SOEST Contribution 7591; UTIG Contribution 2051.

\section{References}

Ando, M., 1975. Source mechanisms and tectonic significance of historical earthquakes along the Nankai Trough, Japan. Tectonophysics, 27(2):119-140. doi:10.1016/0040-1951(75)90102-X

Aoki, Y., Tamano, T., and Kato, S., 1982. Detailed structure of the Nankai Trough from migrated seismic sections. In Watkins, J.S., and Drake, C.L. (Eds.), Studies in Continental Margin Geology. AAPG Mem., 34:309-322.

Ashi, J., Kuramoto, S., Morita, S., Tsunogai, U., Goto, S., Kojima, S., Okamoto, T., Ishimura, T., Ijiri, A., Toki, T., Kudo, S., Asai, S., and Utsumi, M., 2002. Structure and cold seep of the Nankai accretionary prism off Kumano-outline of the off Kumano survey during YK01-04 Leg 2 cruise. JAMSTEC J. Deep Sea Res., 20:1-8. (in Japanese, with abstract in English)

Baba, T., and Cummins, P.R., 2005. Contiguous rupture areas of two Nankai Trough earthquakes revealed by high-resolution tsunami waveform inversion. Geophys. Res. Lett., 32(8):L08305. doi:10.1029/2004GL022320

Bangs, N.L.B., Moore, G.F., Gulick, S.P.S., Pangborn, E.M., Tobin, H.J., Kuramoto, S., and Taira, A., in press. Broad, weak regions of the Nankai megathrust and implications for shallow coseismic slip. Earth Planet. Sci. Lett.

Dominguez, S., Malavieille, J., and Lallemand, S.E., 2000. Deformation of accretionary wedges in response to seamount subduction: insights from sandbox experiments. Tectonics, 19(1):182-196. doi:10.1029/1999TC900055

Gulick, S.P., Bangs, N.L., Moore, G.F., Martin, K.M., Sawyer, D.S., Nakamura, Y., and Tobin, H.J., 2008. Kumano forearc basin uplift and megasplay fault development: 3-D seismic images of Nankai margin offshore Kii Peninsula, Japan. Eos, Trans. Am. Geophys. Union, 89(53)(Suppl.), T21F-08. (Abstract) 
Gulick, S.P.S., Bangs, N.L.B., Shipley, T.H., Nakamura, Y., Moore, G., and Kuramoto, S., 2004. Three-dimensional architecture of the Nankai accretionary prism's imbricate thrust zone off Cape Muroto, Japan: prism reconstruction via en echelon thrust propagation. J. Geophys. Res., 109(B2):B02105. doi:10.1029/2003JB002654

Ike, T., Moore, G.F., Kuramoto, S., Park, J.-O., Kaneda, Y., and Taira, A., 2008a. Tectonics and sedimentation around Kashinosaki Knoll: a subducting basement high in the eastern Nankai Trough. Isl. Arc, 17(3):358-375. doi:10.1111/j.1440-1738.2008.00625.x

Ike, T., Moore, G.F., Kuramoto, S., Park, J.-O., Kaneda, Y., and Taira, A., 2008b. Variations in sediment thickness and type along the northern Philippine Sea plate at the Nankai Trough. Isl. Arc, 17(3):342-357. doi:10.1111/ j.1440-1738.2008.00624. $\mathrm{x}$

Karig, D.E., Ingle, J.C., Jr., et al., 1975. Init. Repts. DSDP, 31: Washington, DC (U.S. Govt. Printing Office). doi:10.2973/dsdp.proc.31.1975

Kimura, G., Kitamura, Y., Hashimoto, Y., Yamaguchi, A., Shibata, T., Ujiie, K., and Okamoto, S., 2007. Transition of accretionary wedge structures around the up-dip limit of the seismogenic subduction zone. Earth Planet. Sci. Lett., 225(3-4):471-484. doi:10.1016/ j.epsl.2007.01.005

Kington, J.D., Tobin, H., and Moore, G., 2008. Fold thrust belt kinematics from 3-D seismic imaging along the NanTroSEIZE transect, Nankai accretionary prism, Japan. Eos, Trans. Am. Geophys. Union, 89(53)(Suppl.):T31A-1969. (Abstract)

Kodaira, S., Hori, T., Ito, A., Miura, S., Fujie, G., Park, J.-O., Baba, T., Sakaguchi, H., and Kaneda, Y., 2006. A cause of rupture segmentation and synchronization in the Nankai Trough revealed by seismic imaging and numerical simulation. J. Geophys. Res., [Solid Earth], 111(B9):B09301. doi:10.1029/2005JB004030

Lallemand, S., and Le Pichon, X., 1987. Coulomb wedge model applied to the subduction of seamounts in the Japan Trench. Geology, 15(11):1065-1069. doi:10.1130/ 0091-7613(1987)15<1065:CWMATT>2.0.CO;2

Martin, K.M., Gulick, S.P., Bangs, N.L., Moore, G.F., Kuramoto, S., Tobin, H., and Taira, A., 2007. Preliminary analysis of an anomalous bathymetric "notch" between the Kumano forearc basin and the slope of the Nankai Trough accretionary prism. Eos, Trans. Am. Geophys. Union, 88(52):T53A-1115.

Martin, K.M., Gulick, S.P., Bangs, N.L., Ashi, J., Moore, G.F., Nakamura, Y., and Tobin, H.J., 2008. Possible strain partitioning between the Kumano forearc basin and the slope of the Nankai Trough accretionary prism. Eos, Trans. Am. Geophys. Union, 89(53)(Suppl.):T31B-2006. (Abstract)

Miyazaki, S., and Heki, K., 2001. Crustal velocity field of southwest Japan: subduction and arc-arc collision. J. Geophys. Res., 106(B3):4305-4326. doi:10.1029/ 2000JB900312

Moore, G.F., Bangs, N.L., Taira, A., Kuramoto, S., Pangborn, E., and Tobin, H.J., 2007. Three-dimensional splay fault geometry and implications for tsunami generation. Sci- ence, 318(5853):1128-1131. doi:10.1126/science. 1147195

Moore, G.F., Shipley, T.H., Stoffa, P.L., Karig, D.E., Taira, A., Kuramoto, S., Tokuyama, H., and Suyehiro, K., 1990. Structure of the Nankai Trough accretionary zone from multichannel seismic reflection data. J. Geophys. Res., 95(B6):8753-8765. doi:10.1029/JB095iB06p08753

Moore, G.F., Taira, A., Klaus, A., Becker, L., Boeckel, B., Cragg, B.A., Dean, A., Fergusson, C.L., Henry, P., Hirano, S., Hisamitsu, T., Hunze, S., Kastner, M., Maltman, A.J., Morgan, J.K., Murakami, Y., Saffer, D.M., SánchezGómez, M., Screaton, E.J., Smith, D.C., Spivack, A.J., Steurer, J., Tobin, H.J., Ujiie, K., Underwood, M.B., and Wilson, M., 2001. New insights into deformation and fluid flow processes in the Nankai Trough accretionary prism: results of Ocean Drilling Program Leg 190. Geochem., Geophys., Geosyst., 2(10):1058. doi:10.1029/ 2001GC000166

Nakanishi, A., Kodaira, S., Miura, S., Ito, A., Sato, T., Park, J.-O., Kido, Y., and Kaneda, Y., 2008. Detailed structural image around splay-fault branching in the Nankai subduction zone: results from a high-density ocean bottom seismic survey. J. Geophys. Res., 113(B3):B03105. doi:10.1029/2007JB004974

Okino, K., and Kato, Y., 1995. Geomorphological study on a clastic accretionary prism: the Nankai Trough. Isl. Arc, 4(3):182-198. doi:10.1111/j.1440-

1738.1995.tb00142.x

Okino, K., Shimakawa, Y., and Nagaoka, S., 1994. Evolution of the Shikoku Basin. J. Geomagn. Geoelectr., 46:463-479.

Park, J.-O., Fujie, G., Hori, T., Kodaira, S., Moore, G.F., Bangs, N.L., Kuramoto, S., Fukao, Y., and Taira, A., in press. A low velocity zone revealed by 3-D prestack depth imaging in the Nankai subduction zone off Kii Peninsula, southwest Japan. Earth Planet. Sci. Lett.

Park, J.-O., Tsuru, T., Kaneda, Y., Kono, Y., Kodaira, S., Takahashi, N., and Kinoshita, H., 1999. A subducting seamount beneath the Nankai accretionary prism off Shikoku, southwestern Japan. Geophys. Res. Lett., 26(7):931-934. doi:10.1029/1999GL900134

Park, J.-O., Tsuru, T., Kodaira, S., Cummins, P.R., and Kaneda, Y., 2002a. Splay fault branching along the Nankai subduction zone. Science, 297(5584):1157-1160. doi:10.1126/science.1074111

Park, J.-O., Tsuru, T., Takahashi, N., Hori, T., Kodaira, S., Nakanishi, A., Miura, S., and Kaneda, Y., 2002b. A deep strong reflector of the Nankai accretionary wedge from multichannel seismic data: implications for underplating and interseismic shear stress release. J. Geophys. Res., [Solid Earth], 107(B4):2061. doi:10.1029/2001JB000262

Seno, T., Stein, S., and Gripp, A.E., 1993. A model for the motion of the Philippine Sea plate consistent with NUVEL-1 and geological data. J. Geophys. Res., 98(B10):17941-17948. doi:10.1029/93JB00782

Sheriff, R.E., 1991. Encyclopedic Dictionary of Exploration Geophysics (3rd ed.): Tulsa, OK (Soc. Explor. Geophys.).

Streiff, C.M., Tobin, H.J., and Moore, G.F., 2008. Detailed 3-D architecture of a thrust fault system and associated folding: Nankai Trough accretionary wedge. Eos, Trans. 
Am. Geophys. Union, 89(53)(Suppl.):T31A-1982. (Abstract)

Taira, A., Curewitz, D., et al., 2005. CDEX Technical Report, Volume 1: Nankai Trough Seismogenic Zone Site Survey, Philippine Sea, Offshore Kii Peninsula, Japan.

Taira, A., Hill, I., Firth, J.V., et al., 1991. Proc. ODP, Init. Repts., 131: College Station, TX (Ocean Drilling Program). doi:10.2973/odp.proc.ir.131.1991

Tobin, H.J., and Kinoshita, M., 2006. NanTroSEIZE: the IODP Nankai Trough Seismogenic Zone Experiment. Sci. Drill., 2:23-27. doi:10.2204/iodp.sd.2.06.2006

Tsuji, T., Park, J.-O., Moore, G., Kodaira, S., Fukao, Y., Kuramoto, S., and Bangs, N., in press. Intraoceanic thrusts in the Nankai Trough of the Kii Peninsula: implications for intraplate earthquake. Geophys. Res. Lett.

Zang, S.X., Chen, Q.Y., Ning, J.Y., Shen, Z.K., and Liu, Y.G., 2002. Motion of the Philippine Sea plate consistent with the NUVEL-1A model. Geophys. J. Int., 150(3):809819. doi:10.1046/j.1365-246X.2002.01744.X

Initial receipt: 24 July 2008

Acceptance: 27 January 2009

Publication: 11 March 2009

MS 314315316-102 
Figure F1. Regional bathymetry of northern Shikoku Basin and Nankai Trough region showing previous DSDP/ $\mathrm{ODP}$ and current IODP drilling transects. $\mathrm{FAB}=$ forearc basin. Inset $=$ tectonic map showing plate tectonic setting of the region. IBT = Izu-Bonin Trench, KPR = Kyushu-Palau Ridge, FSC = fossil spreading center, PSP $=$ Philippine Sea plate.

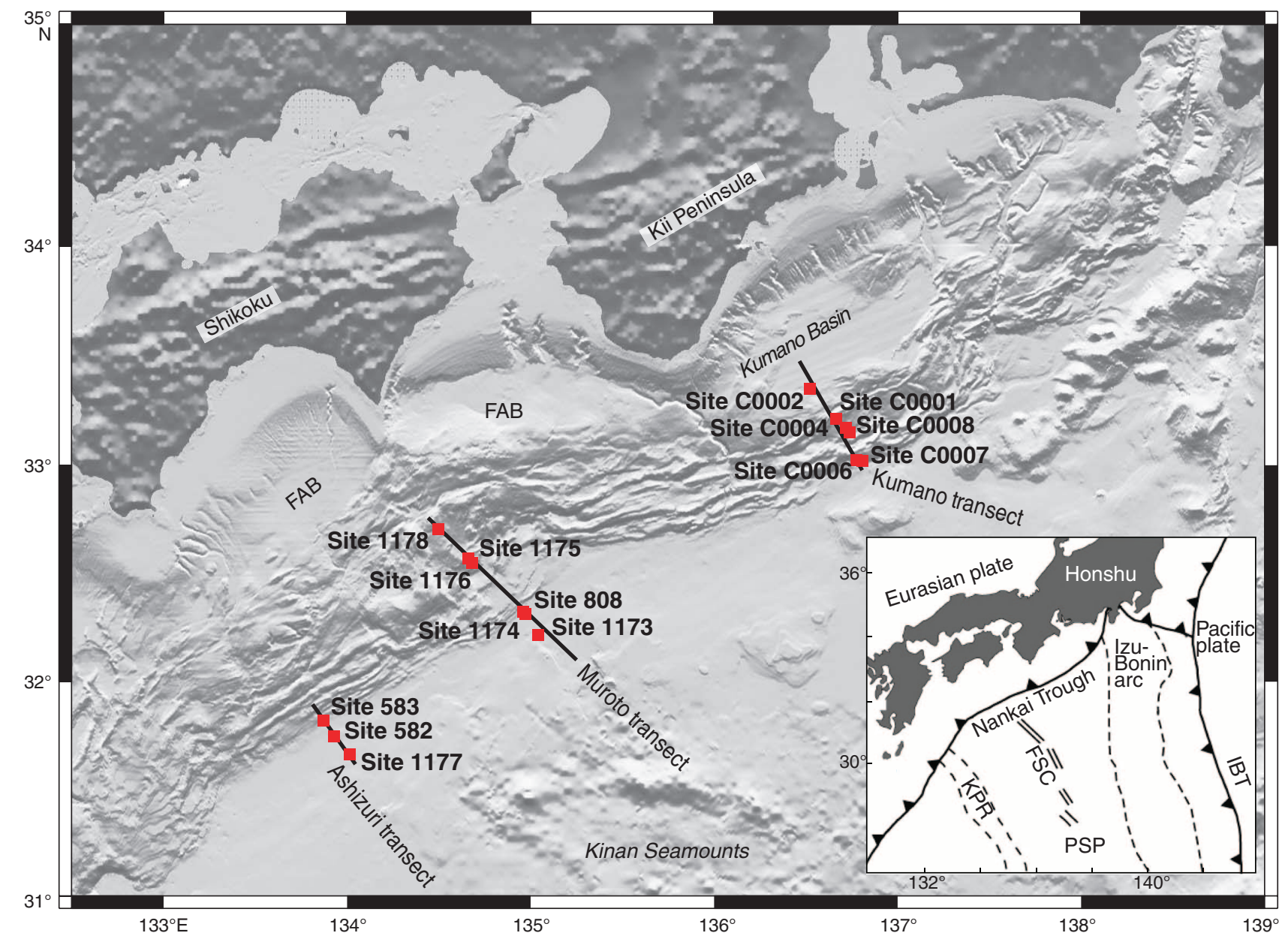


Figure F2. Track plot. Dashed lines = regional 2-D seismic lines collected by JAMSTEC, solid lines $=2003$ CDEX commercial 2-D survey, gray box $=3$-D seismic box, line through drill sites $=$ regional 3-D seismic line shown in Figure F6, circles = NanTroSEIZE Stage 1 drill sites. IL $=$ inline. Details of 2-D seismic data acquisition and processing are summarized in Ike et al. (2008b).

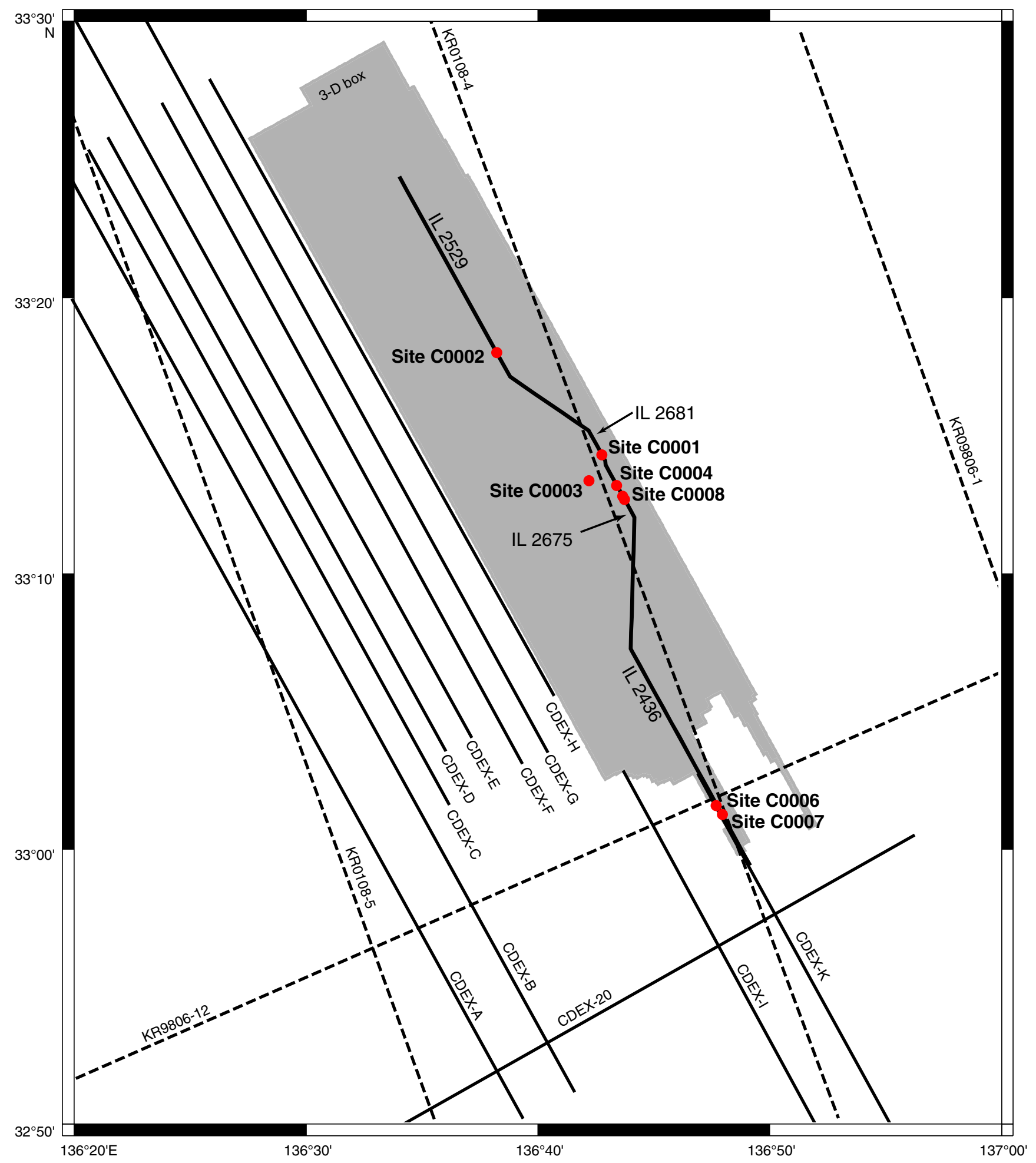


Figure F3. Acquisition geometry for Kumano 3-D seismic survey. STR = streamer.

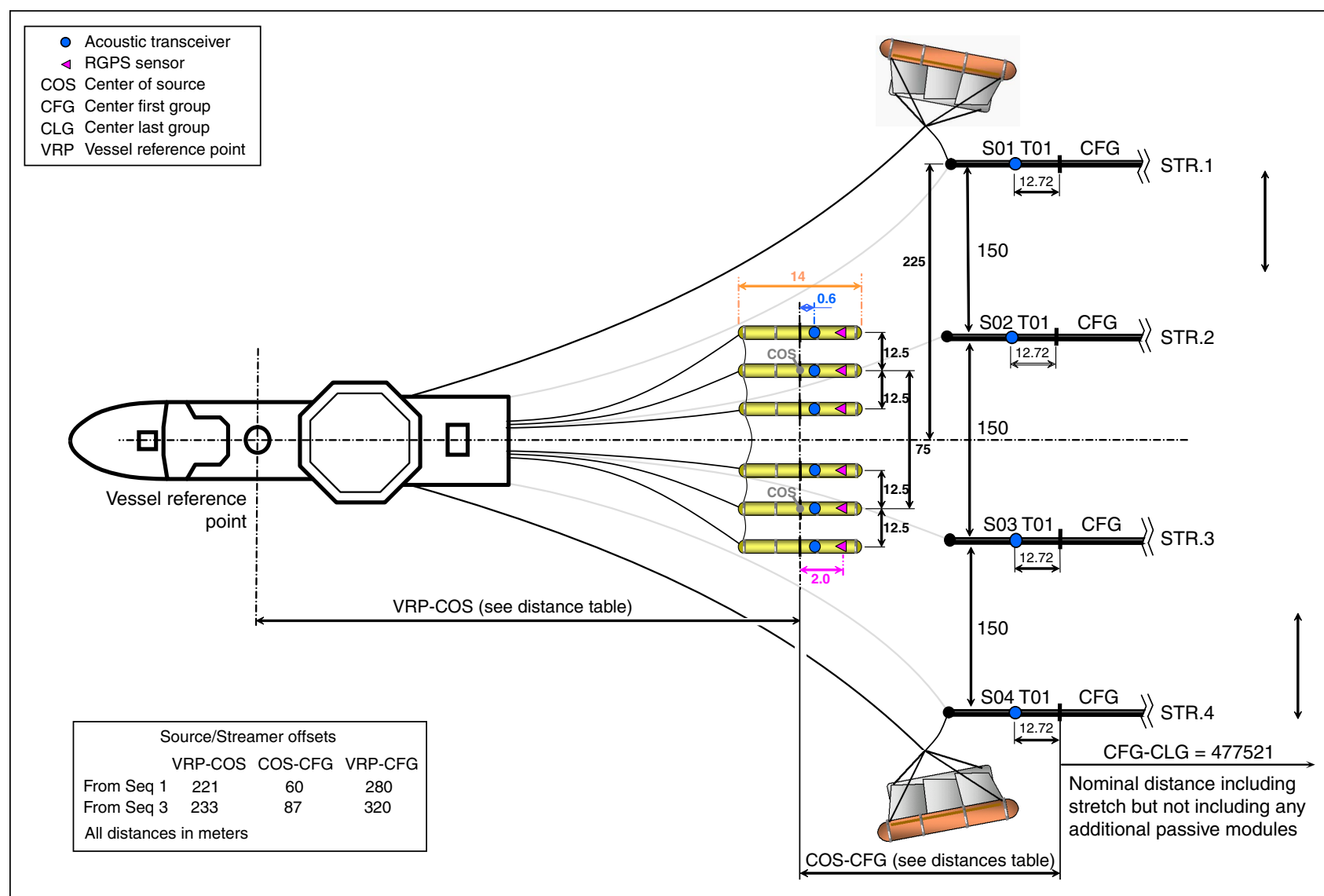

Title: Towing configuration Client: JAMSTEC Job \# 2006020-Kumano-nada 3-D Nankai Trough From Seq \#001 
Figure F4. A. Multibeam bathymetry of the Kumano Basin region. Dashed line $=3$-D seismic survey, circles = NanTroSEIZE Stage 1 drill sites. Details of bathymetry data acquisition and processing are summarized in Ike et al. (2008a). (Continued on next page.)

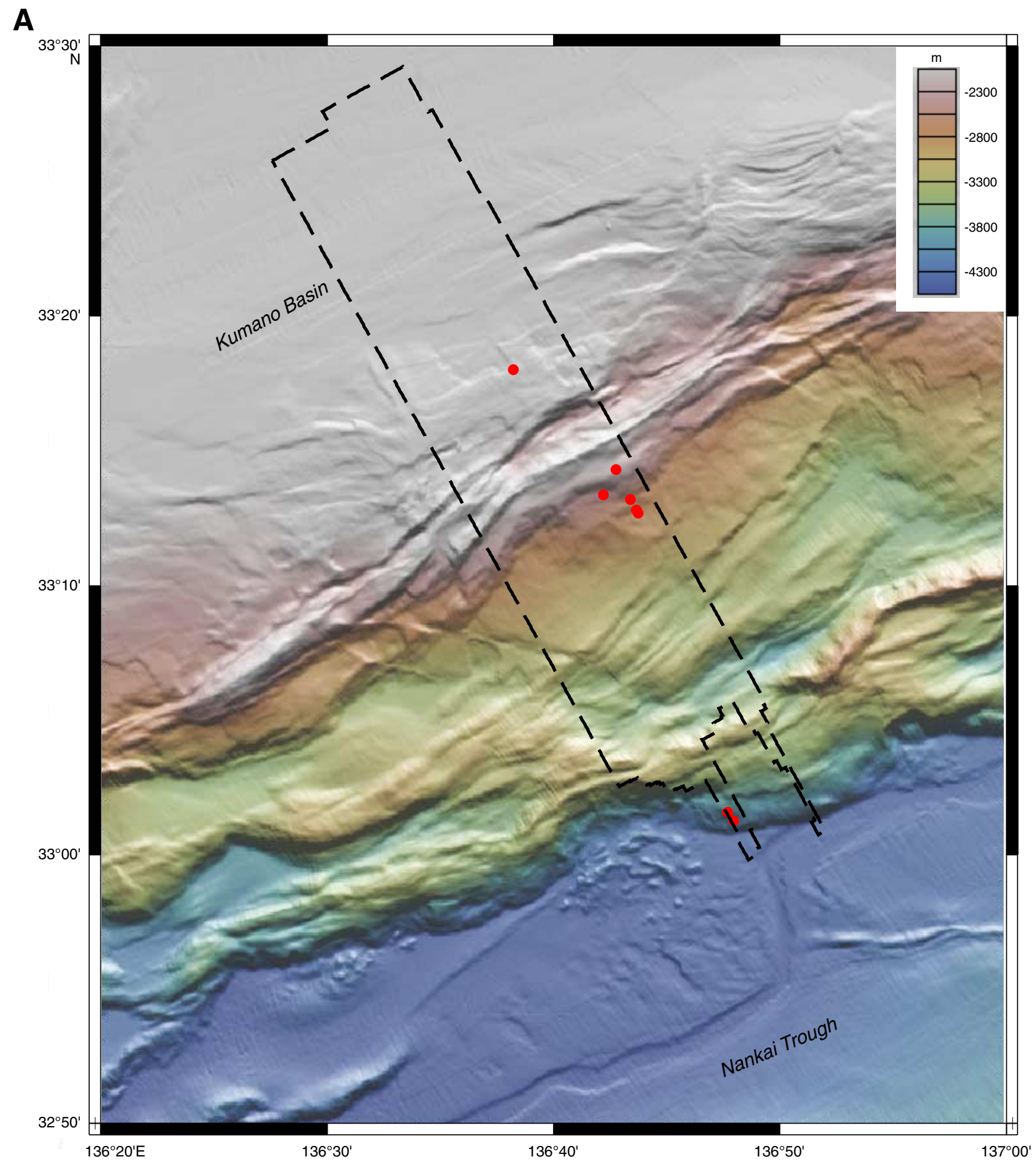


Figure F4 (continued). B. Preliminary geological interpretation of Kumano transect area based on 2-D and 3$\mathrm{D}$ seismic reflection and high-resolution bathymetry data. Solid line $=$ composite seismic line .

B

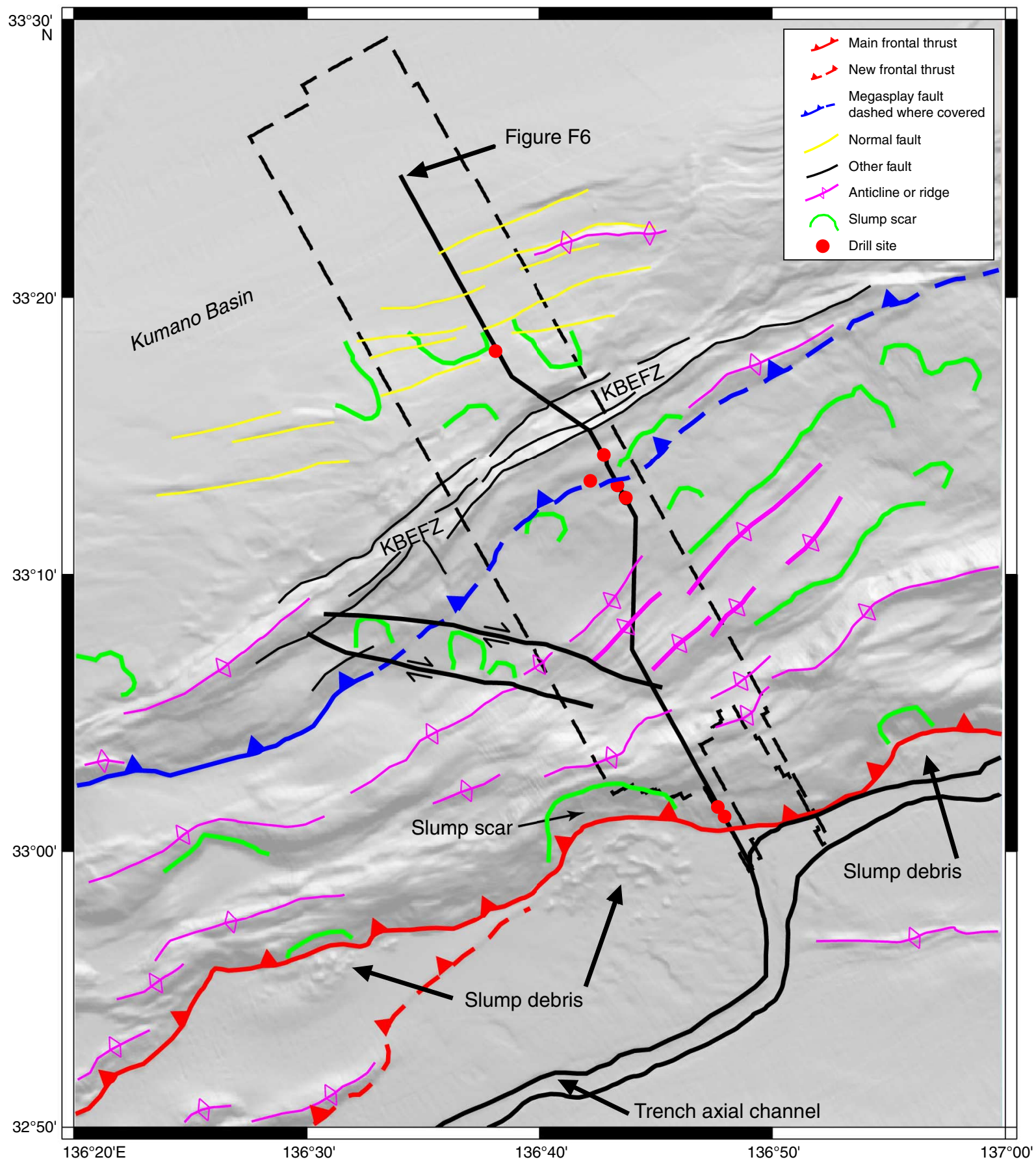


Figure F5. Three-dimensional seismic Inline 2675 showing comparison between (A) PSTM and (B) PSDM. PSDM converted from depth to time using PSDM velocities for easier comparison to PSTM image. Arrows = specific examples of reflections that are clarified in the depth migration. (Continued on next page.)

A

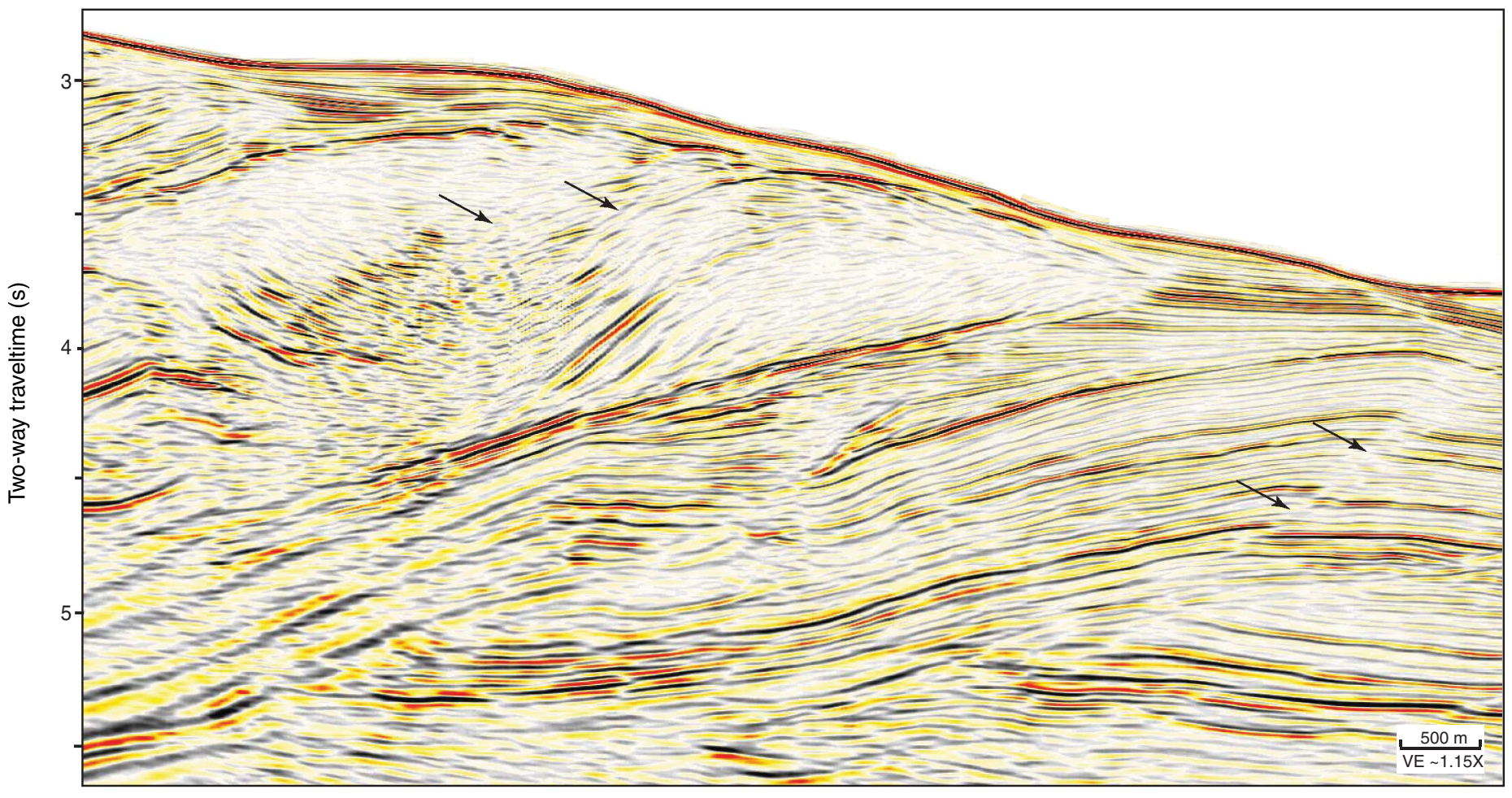


B

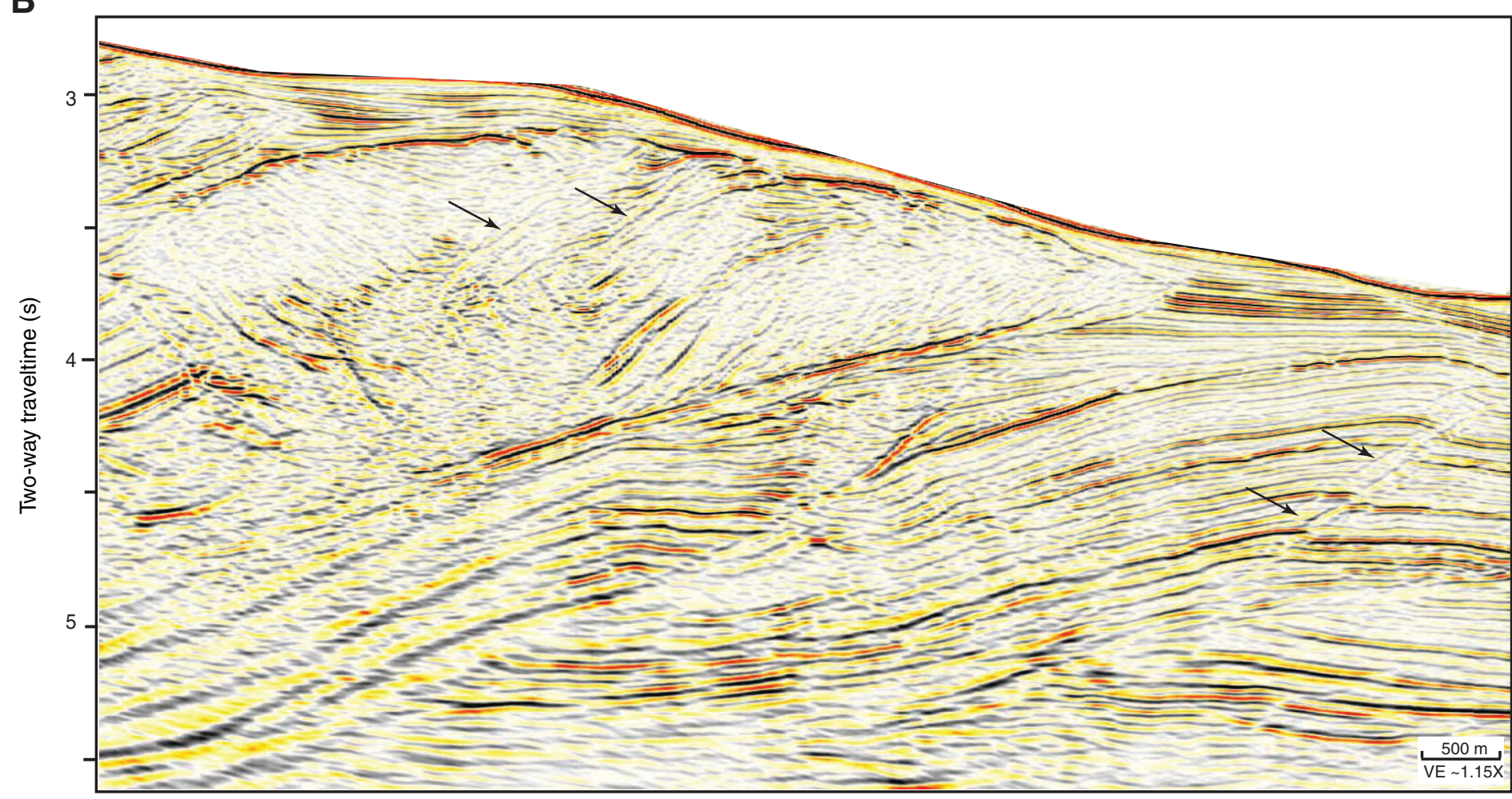


Figure F6. Composite seismic line extracted from 3-D seismic volume. The line crosses through (or near) all Stage 1 drill sites (location shown in Figs. F2 and F4). A. Uninterpreted version. B. Interpreted version. Only a few representative faults are shown. Dashed lines $=$ less certain fault locations. Morphotectonic zones are shown between the two sections. KBEFZ $=$ Kumano Basin edge fault zone, PTZ $=$ protothrust zone. $\mathrm{BSR}=$ bottom-simulating reflector. $\mathrm{VE}=$ vertical exaggeration.

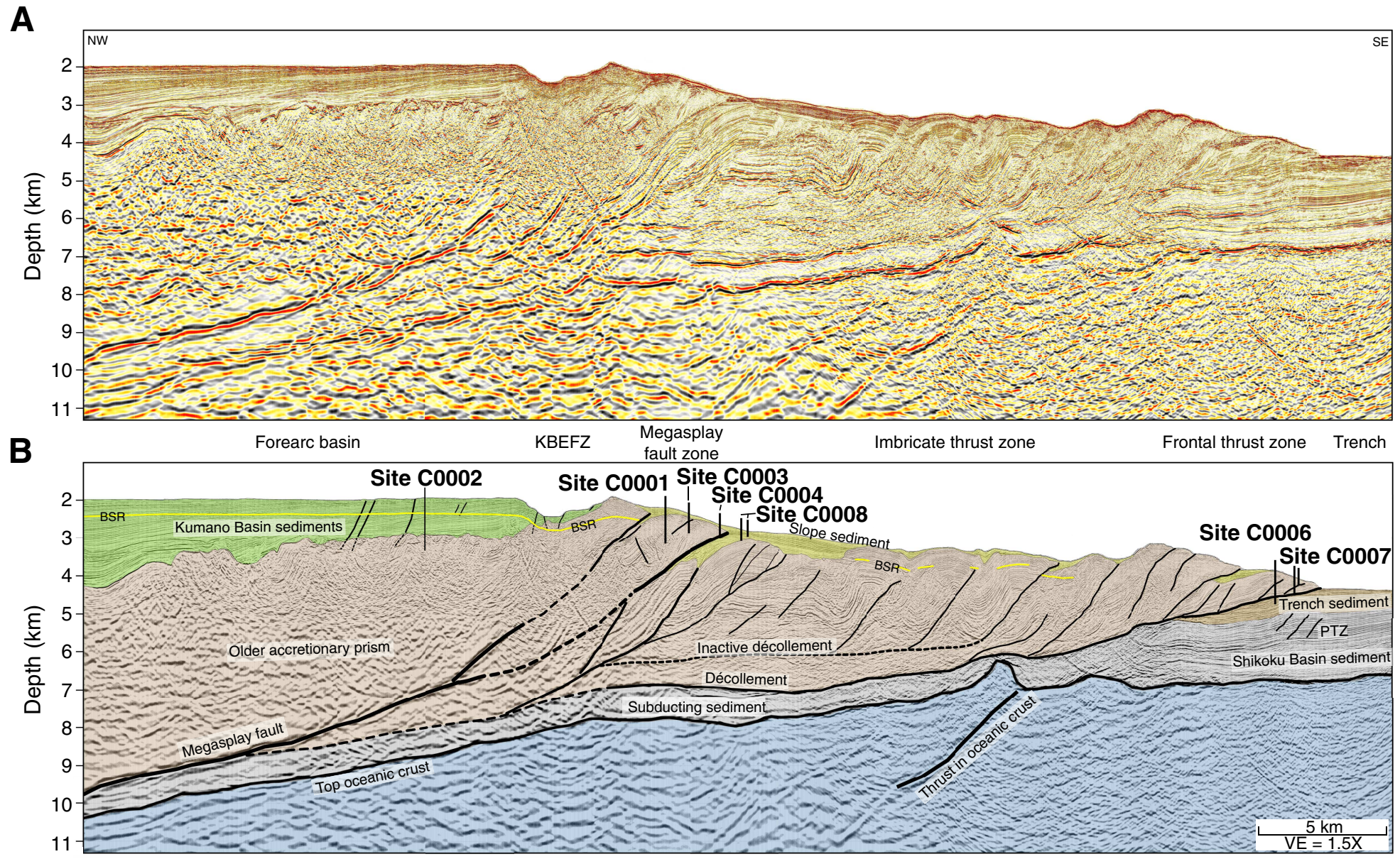


Figure F7. Regional bathymetry, Sites C0006 and C0007. Note the large landslide scar with debris on the trench in front of the scar. The drill sites are at the northeast margin of this slump scar. IL = inline.

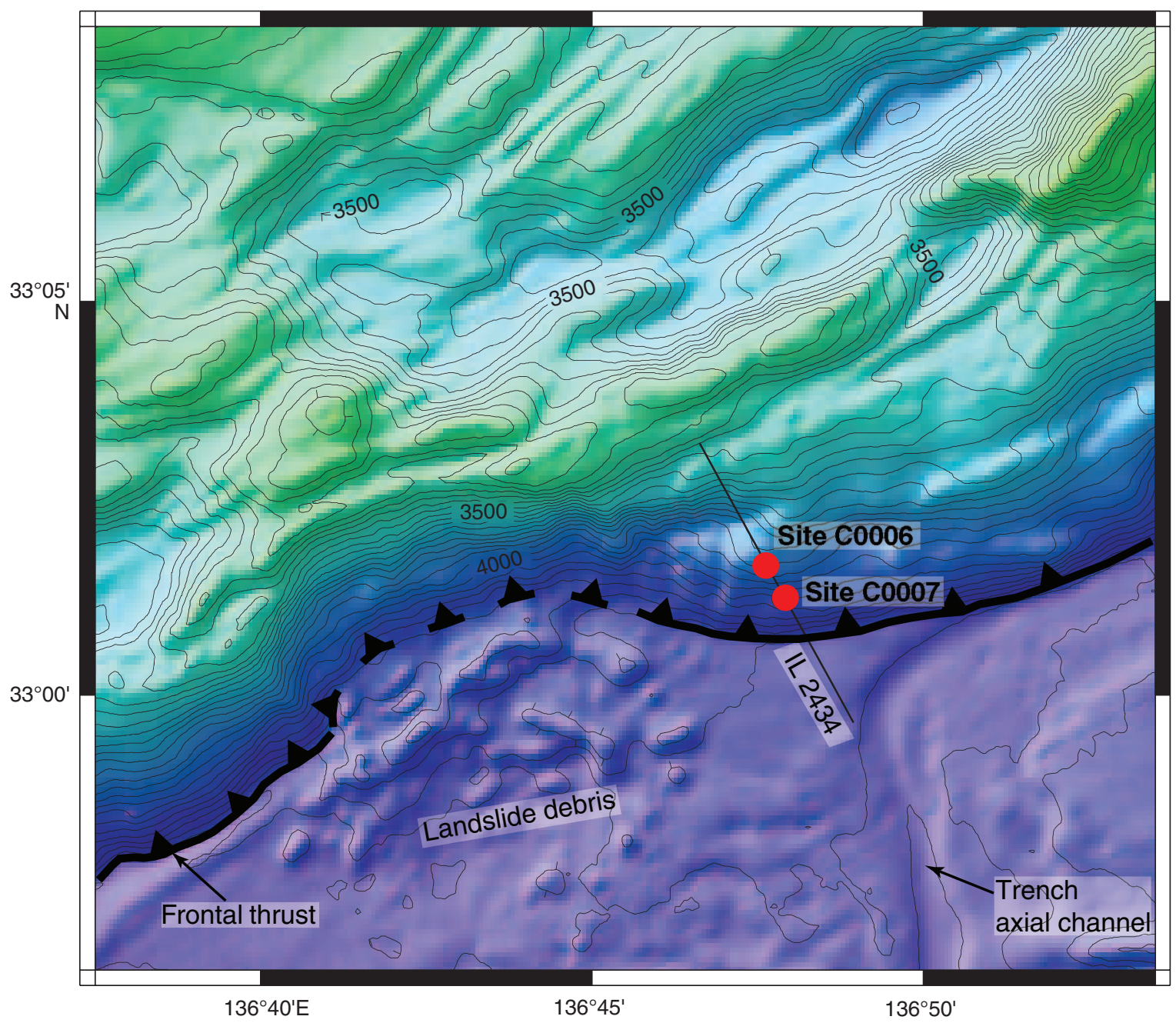


Figure F8. Regional seismic line crossing Sites C0006 and C0007 (location shown in Fig. F7). A. Uninterpreted version. IL $=$ inline. VE $=$ vertical exaggeration. (Continued on next page.)

A

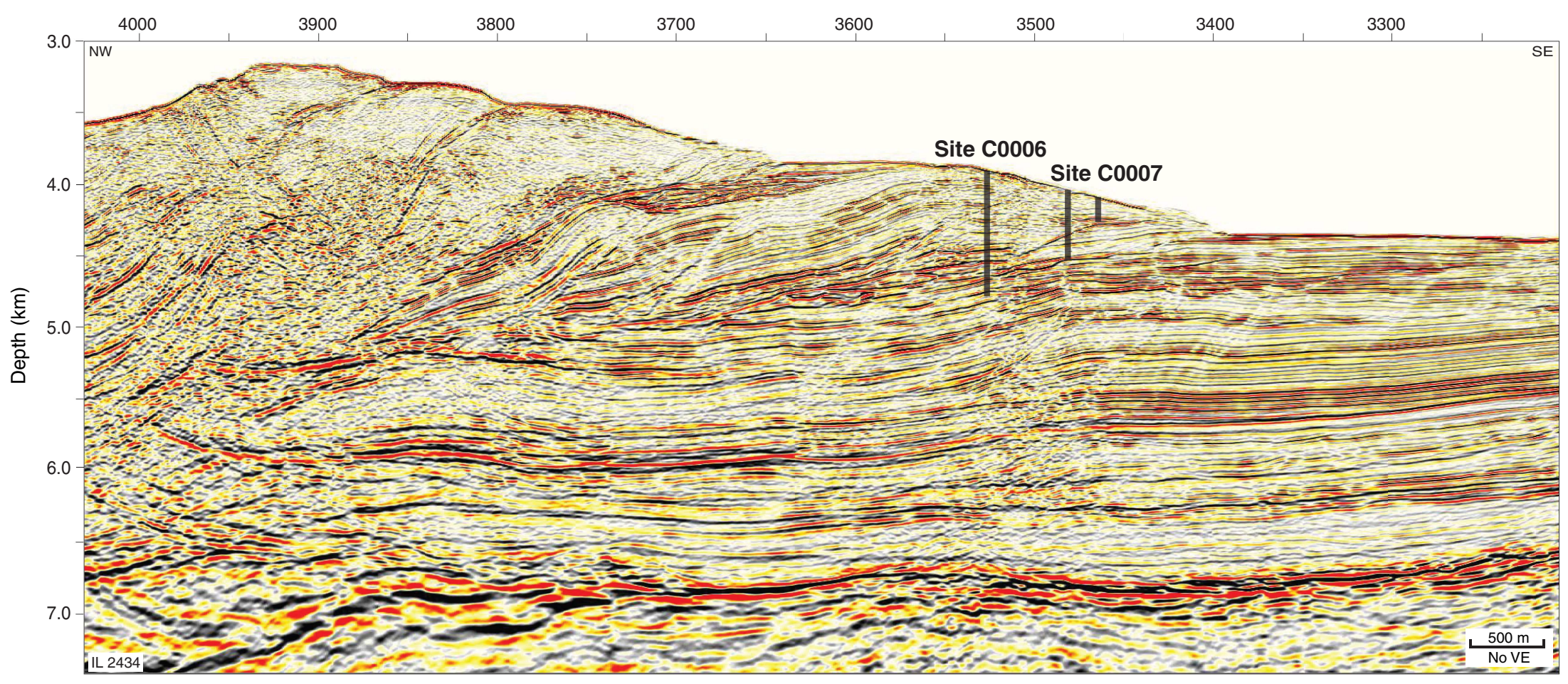




\section{B}

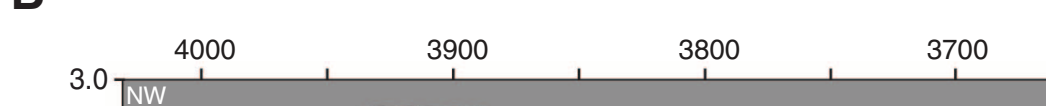

Cross-line 3600
3500
3400

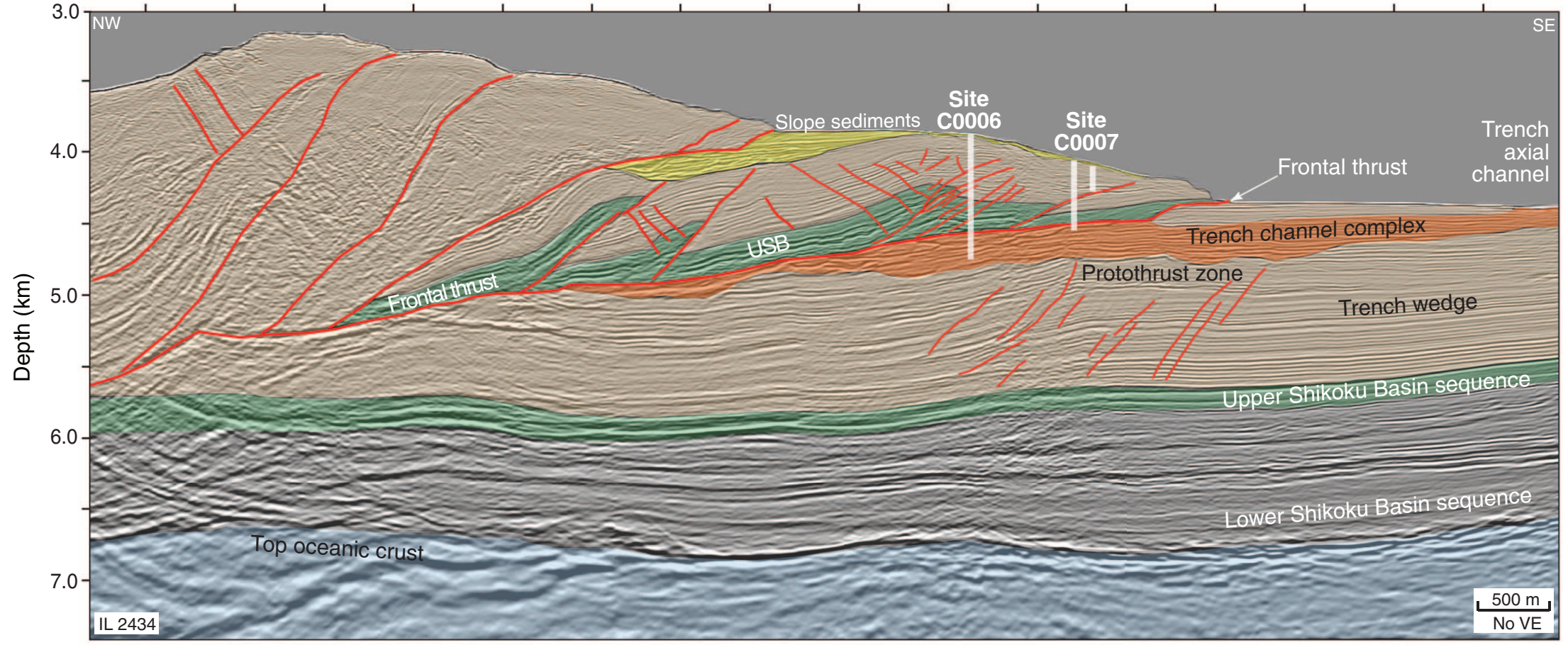


Figure F9. Seismic inline (IL) crossing Sites C0006 and C0007 (location shown in Fig. F7). VE = vertical exaggeration. A. Uninterpreted version. (Continued on next page.)

A

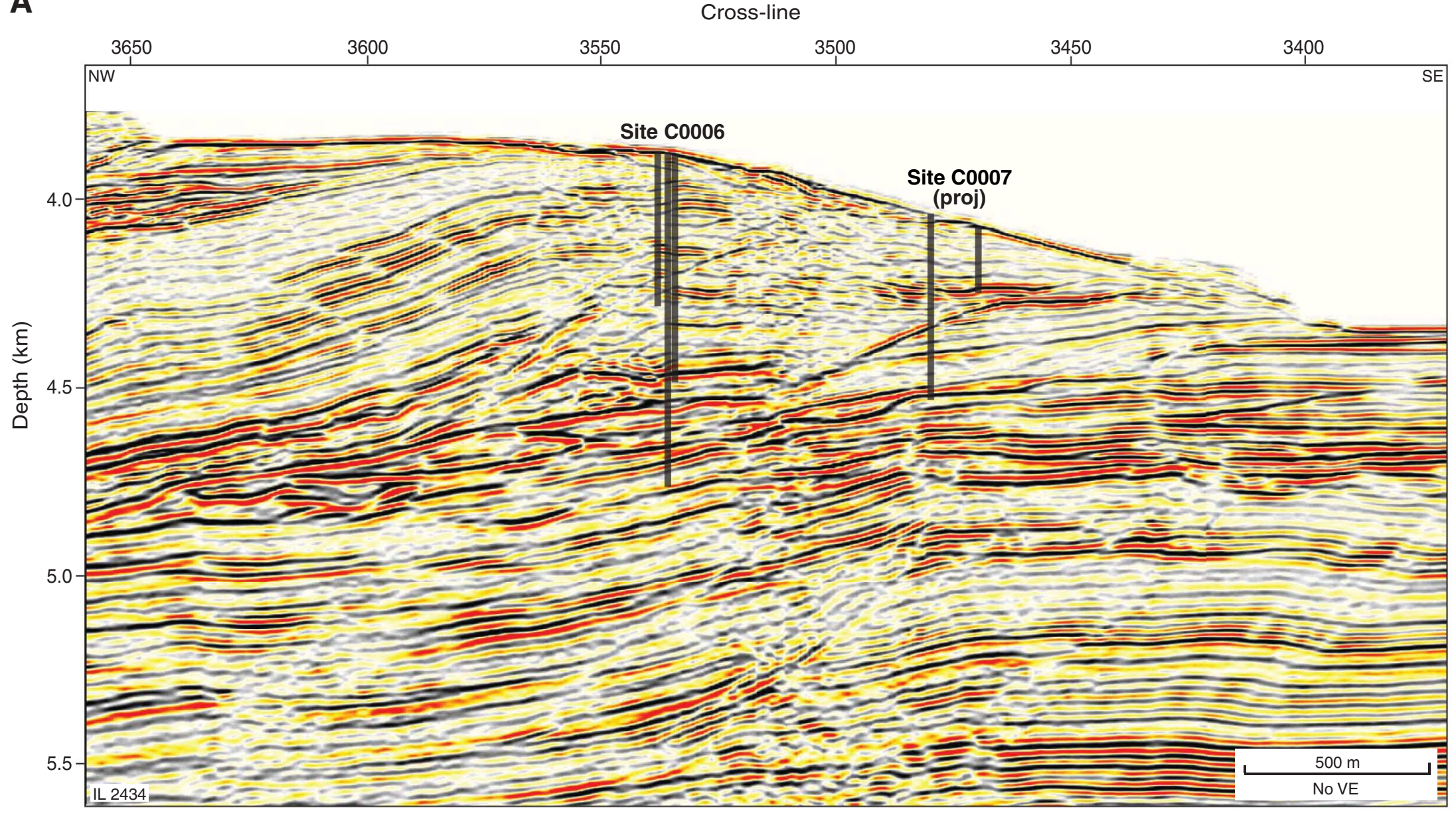




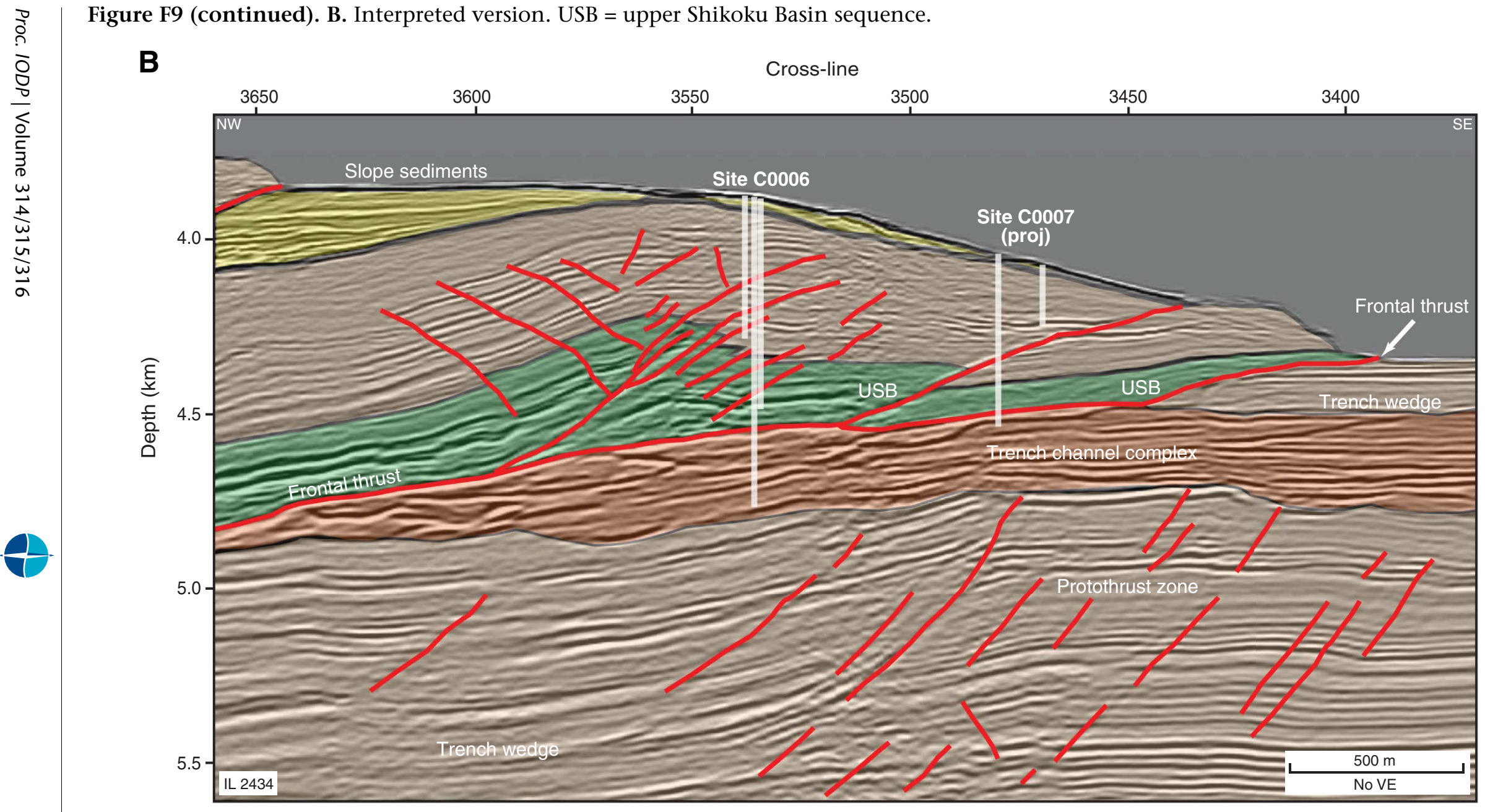


Figure F10. Regional bathymetry, Sites C0001, C0003, C0004, and C0008. IL = inline, XL = cross-line.

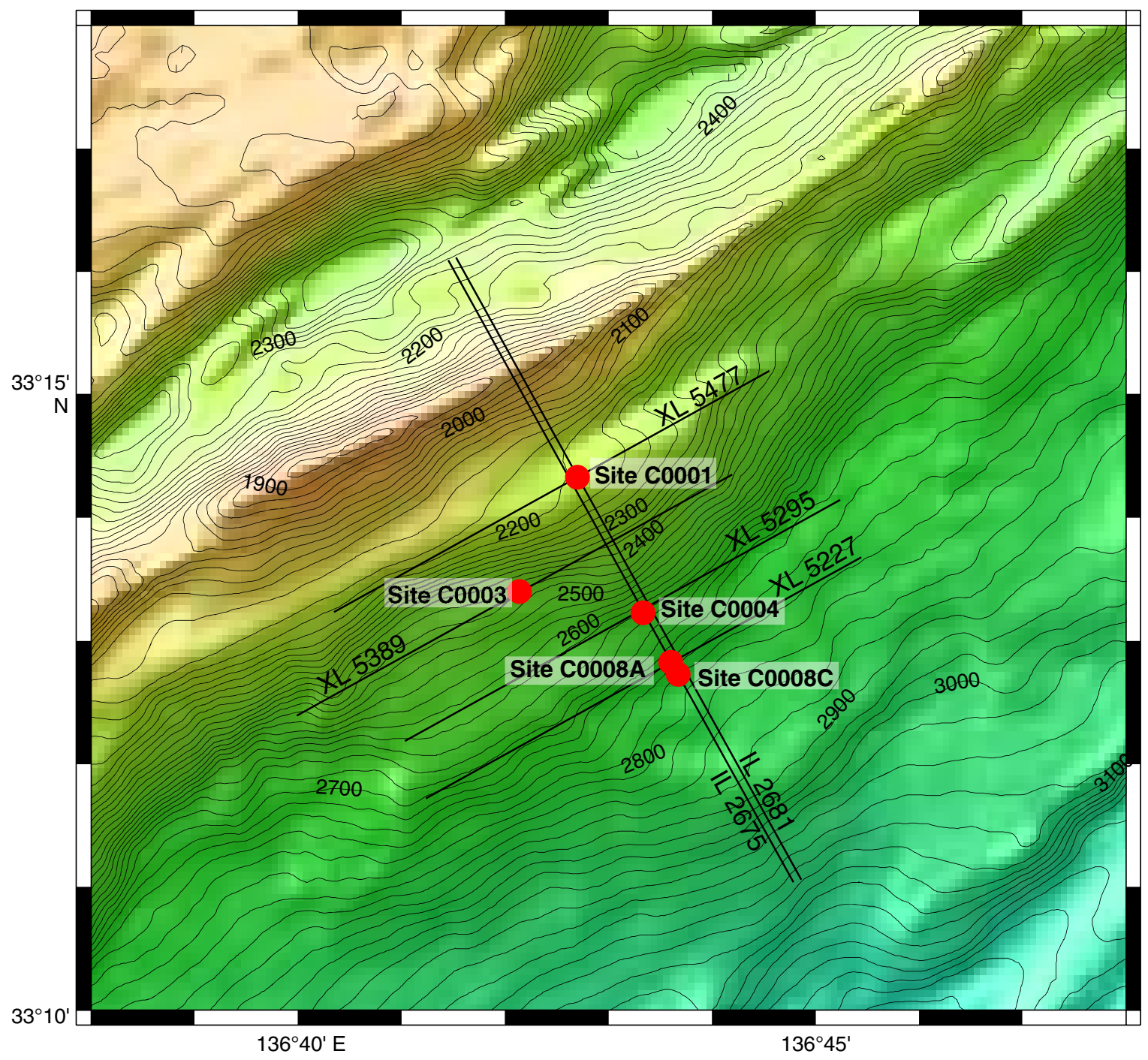




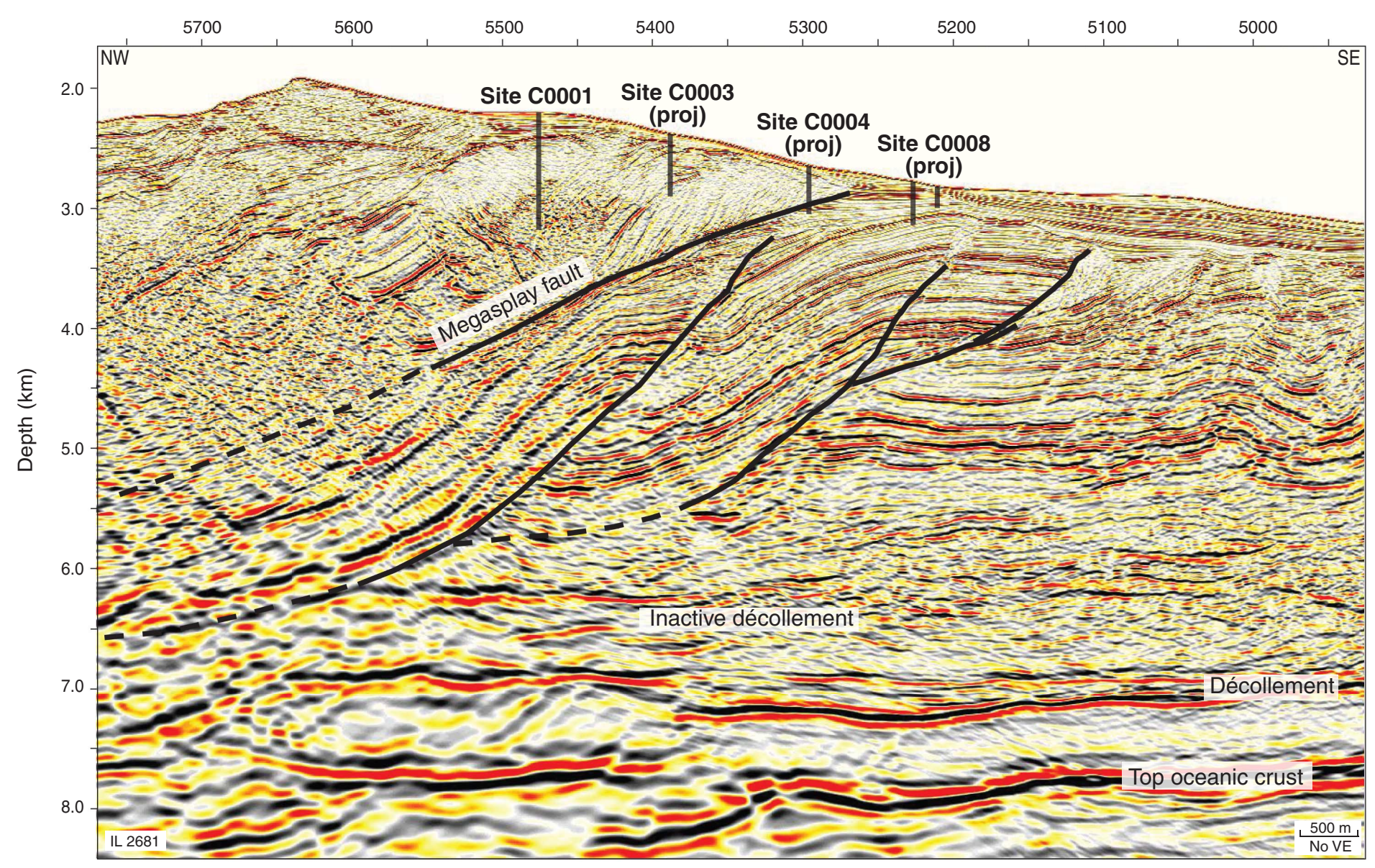


Figure F12. Regional seismic inline (IL) crossing Sites C0004 and C0008 (location shown in Fig. F10). VE = vertical exaggeration.

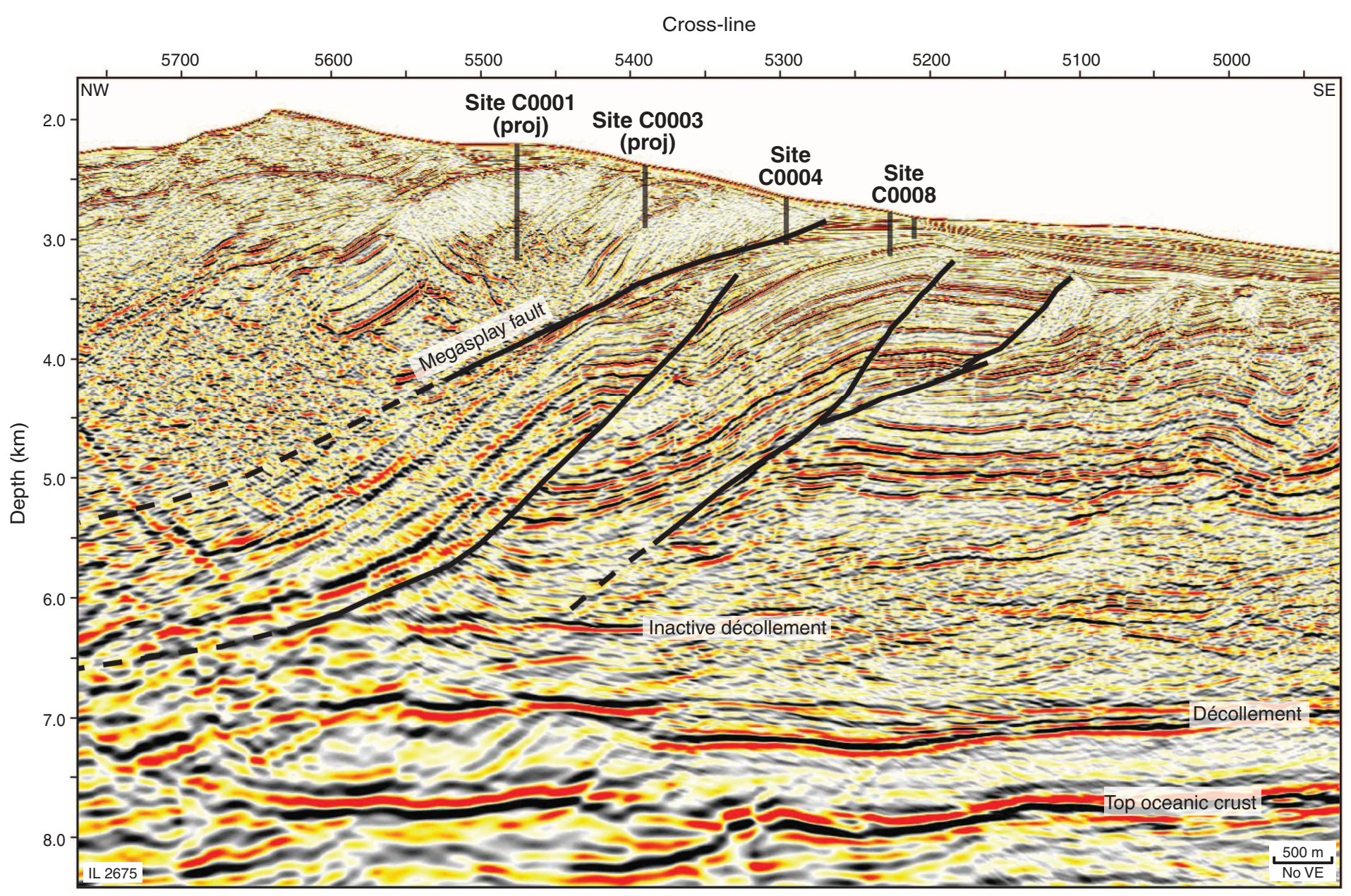


Figure F13. Regional seismic cross-lines (XL) crossing splay fault area drill sites (location shown in Fig. F10). A. Site C0001. VE = vertical exaggeration. (Continued on next two pages.)

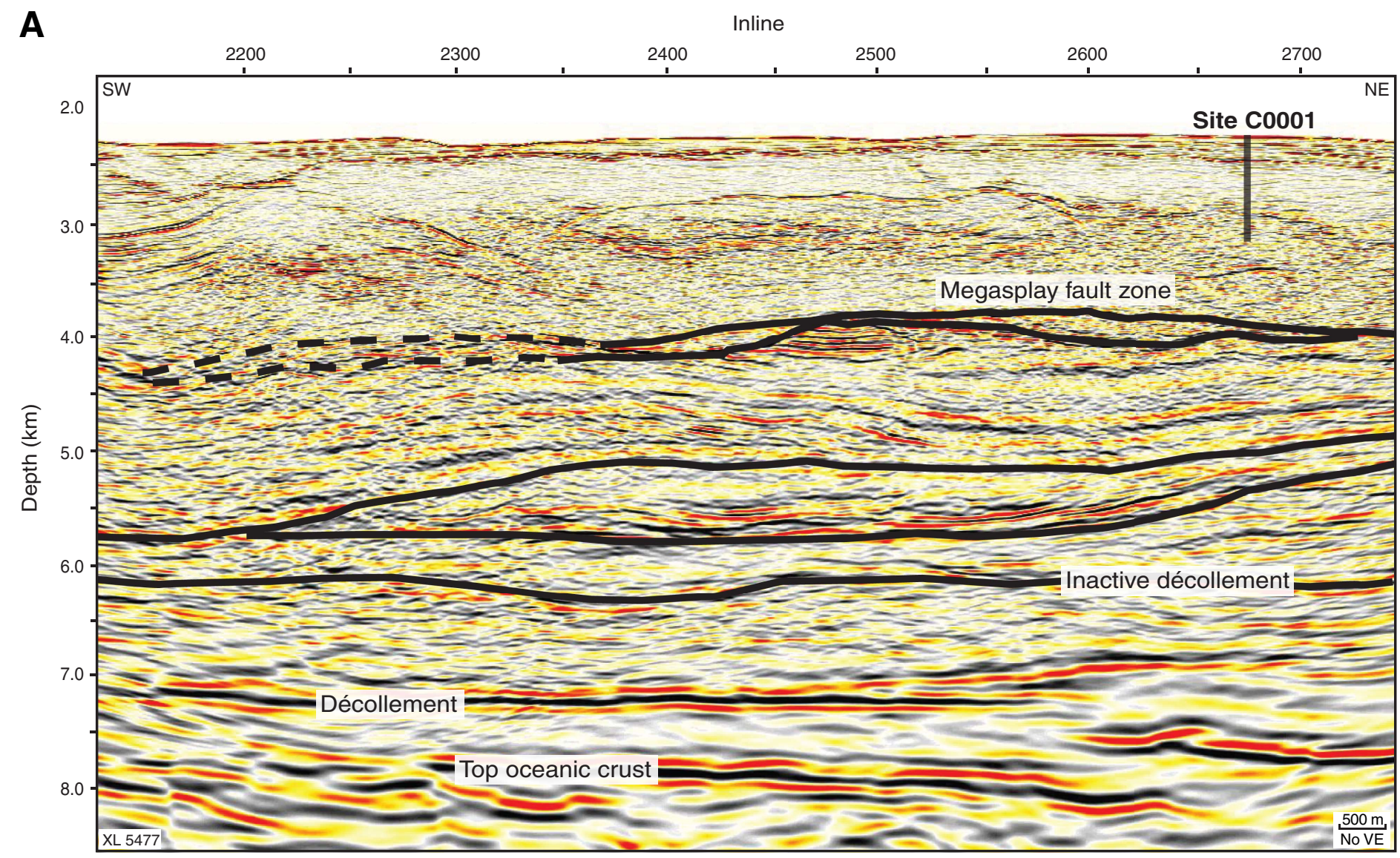


B

Inline

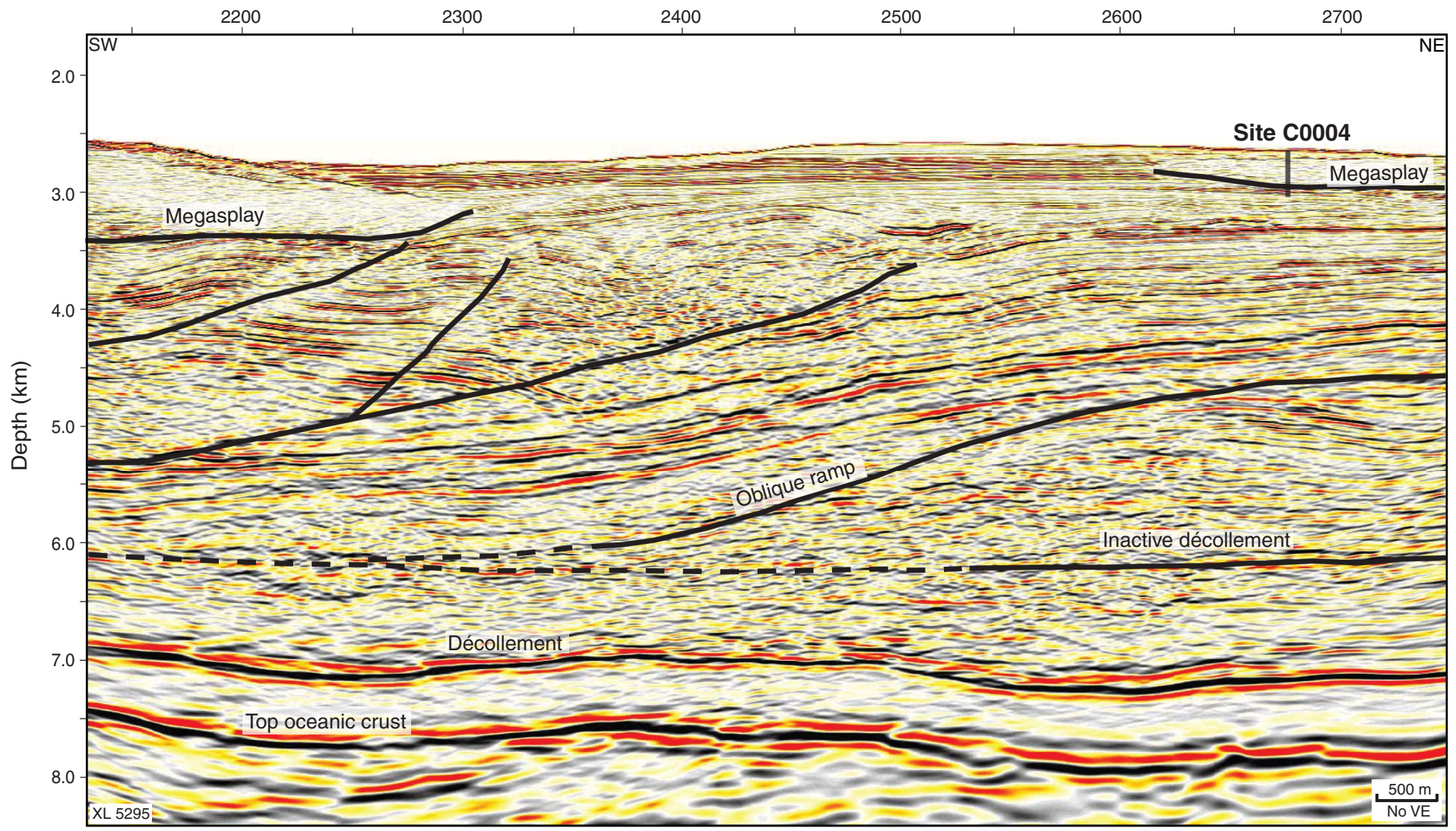


C

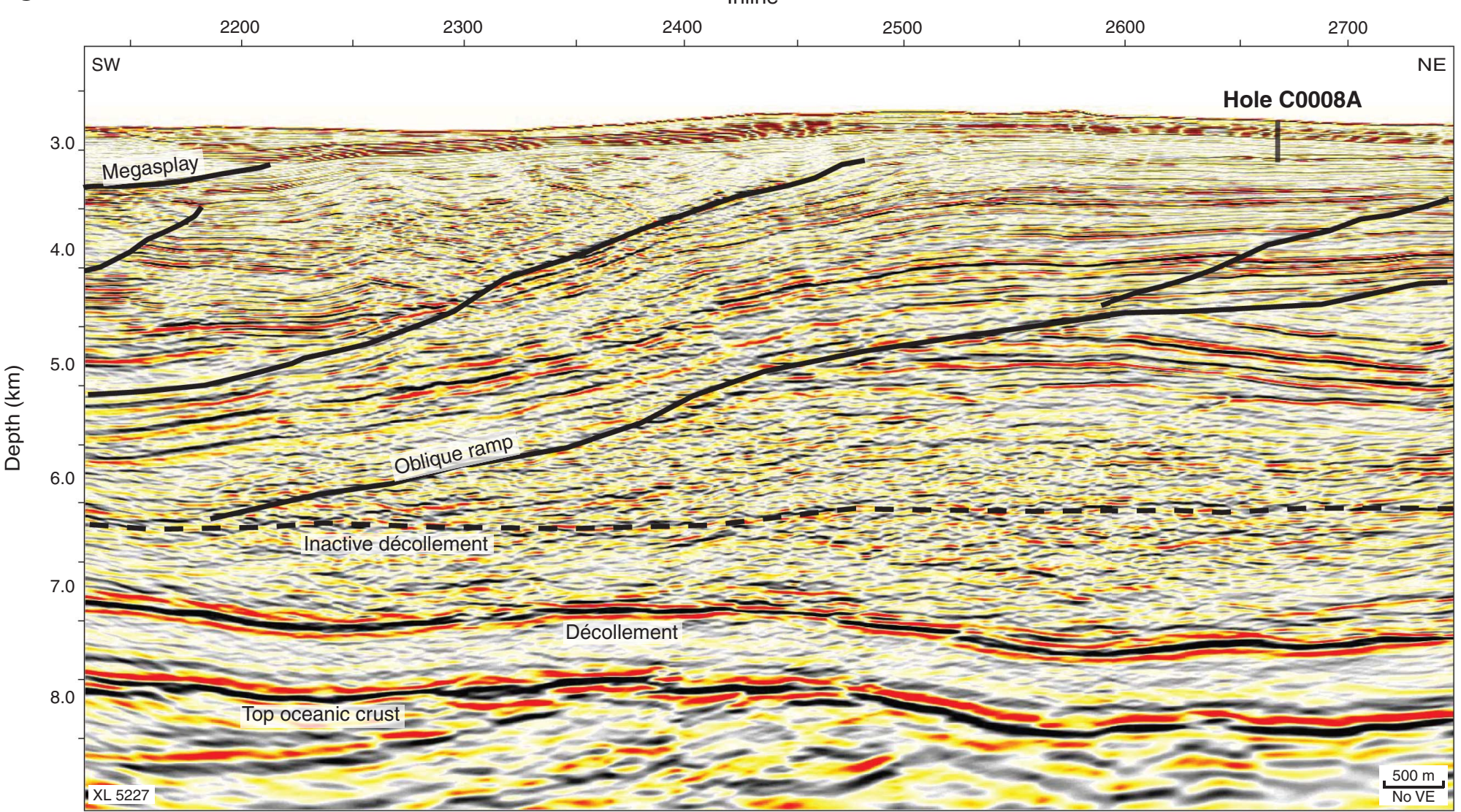


Figure F14. Detail of seismic inline (IL) crossing Site C0001 (location shown in Fig. F10). A. Uninterpreted version. VE = vertical exaggeration. (Continued on next page.)

A

Cross-line

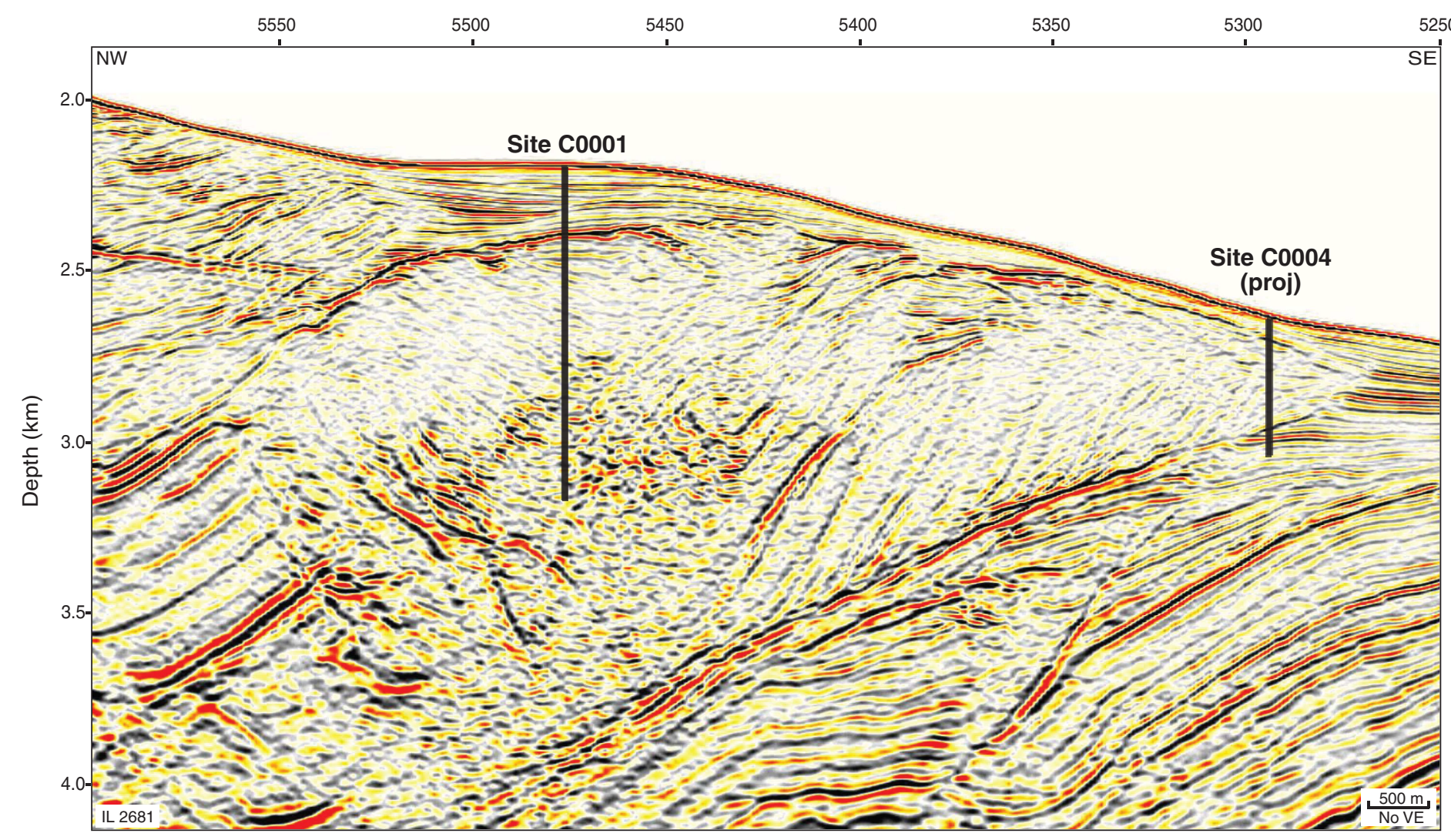




\title{
B
}

\author{
Cross-line
}

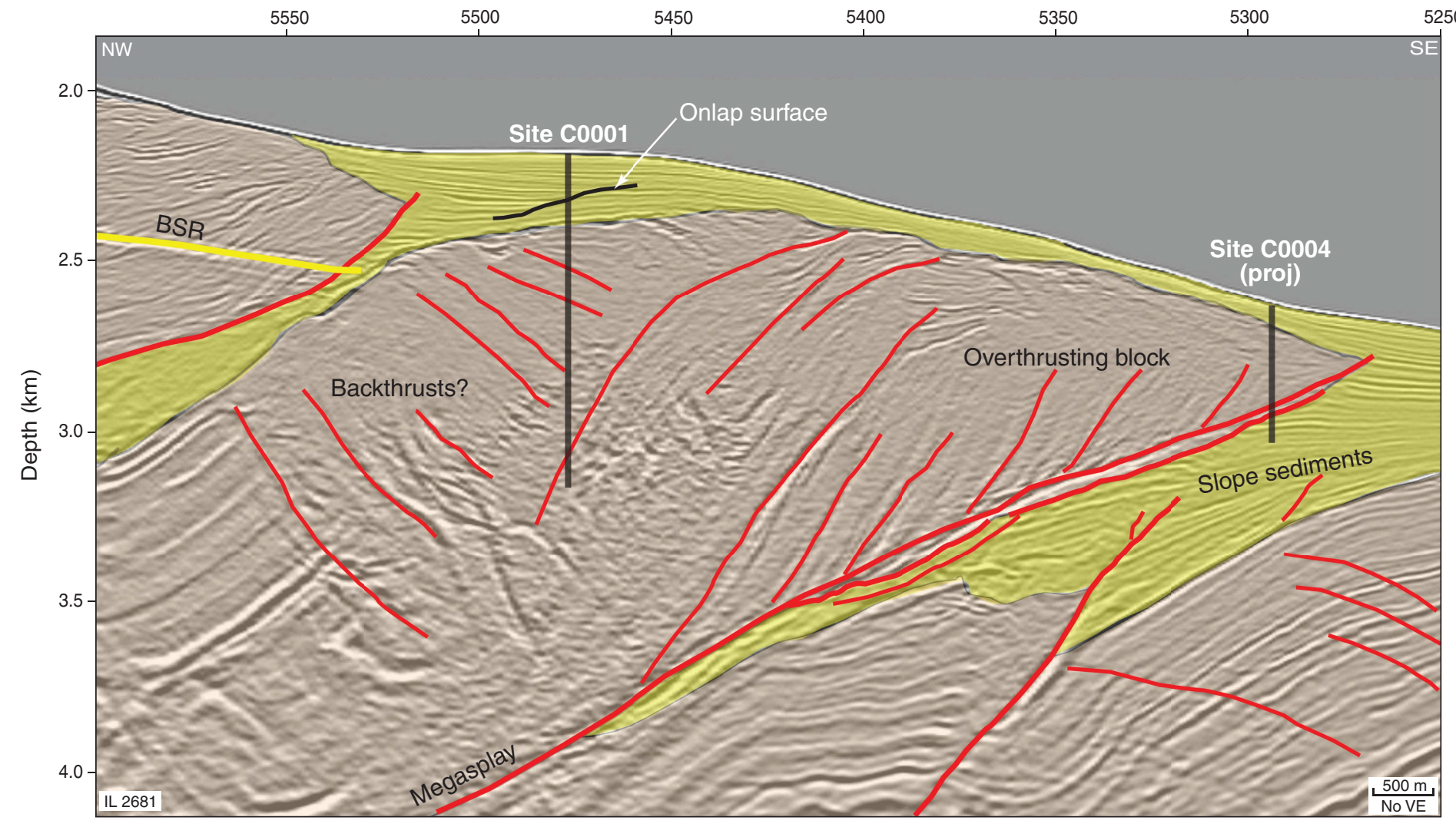


Figure F15. Detail of seismic cross-line (XL) crossing Site C0001 (location shown in Fig. F10). A. Uninterpreted version. VE = vertical exaggeration. (Continued on next page.)

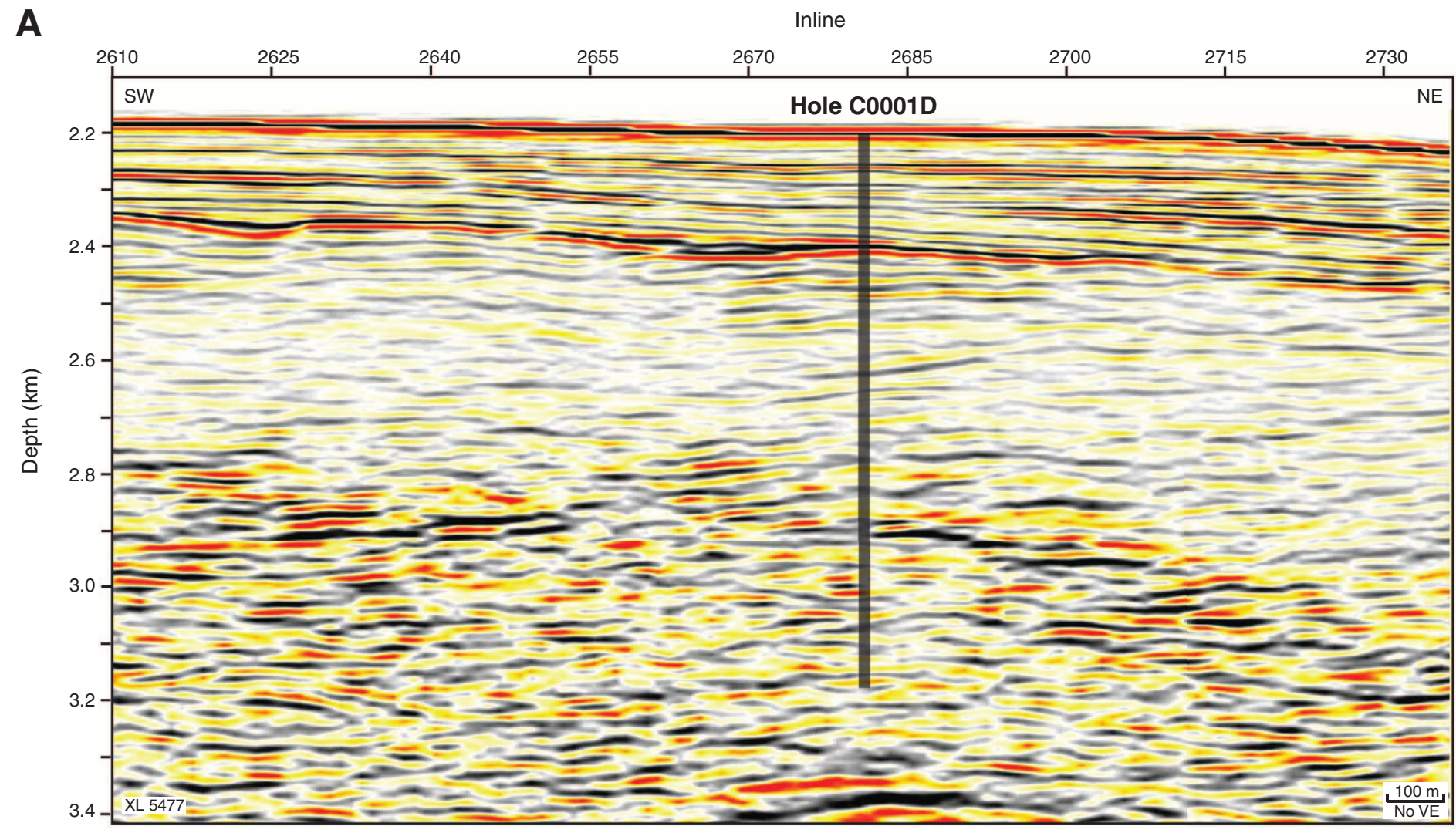




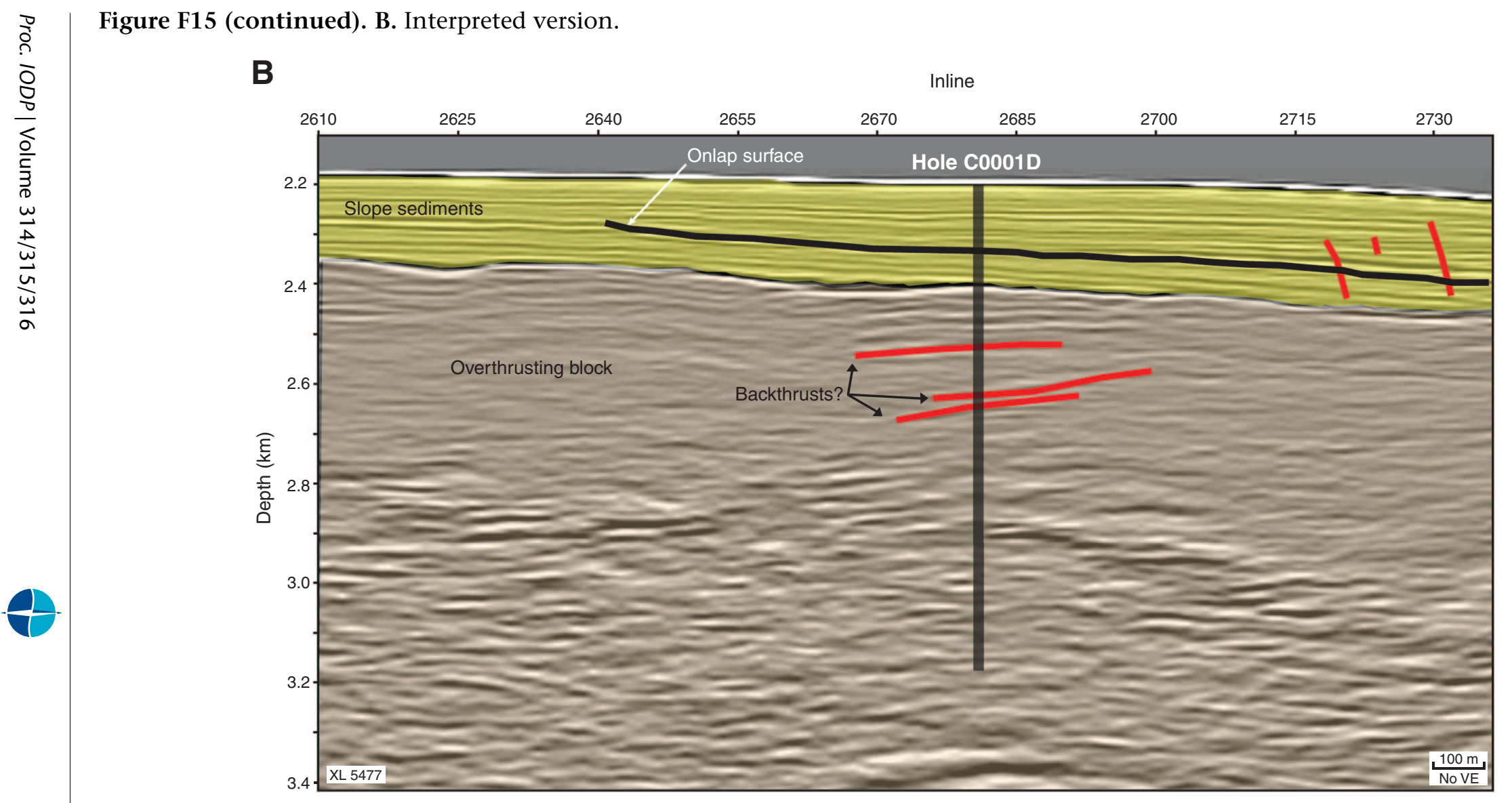


Figure F16. Detail of seismic inline (IL) crossing Site C0004 and Holes C0008A and C0008C (location shown in Fig. F10). A. Uninterpreted version. $\mathrm{VE}=$ vertical exaggeration. (Continued on next page.)

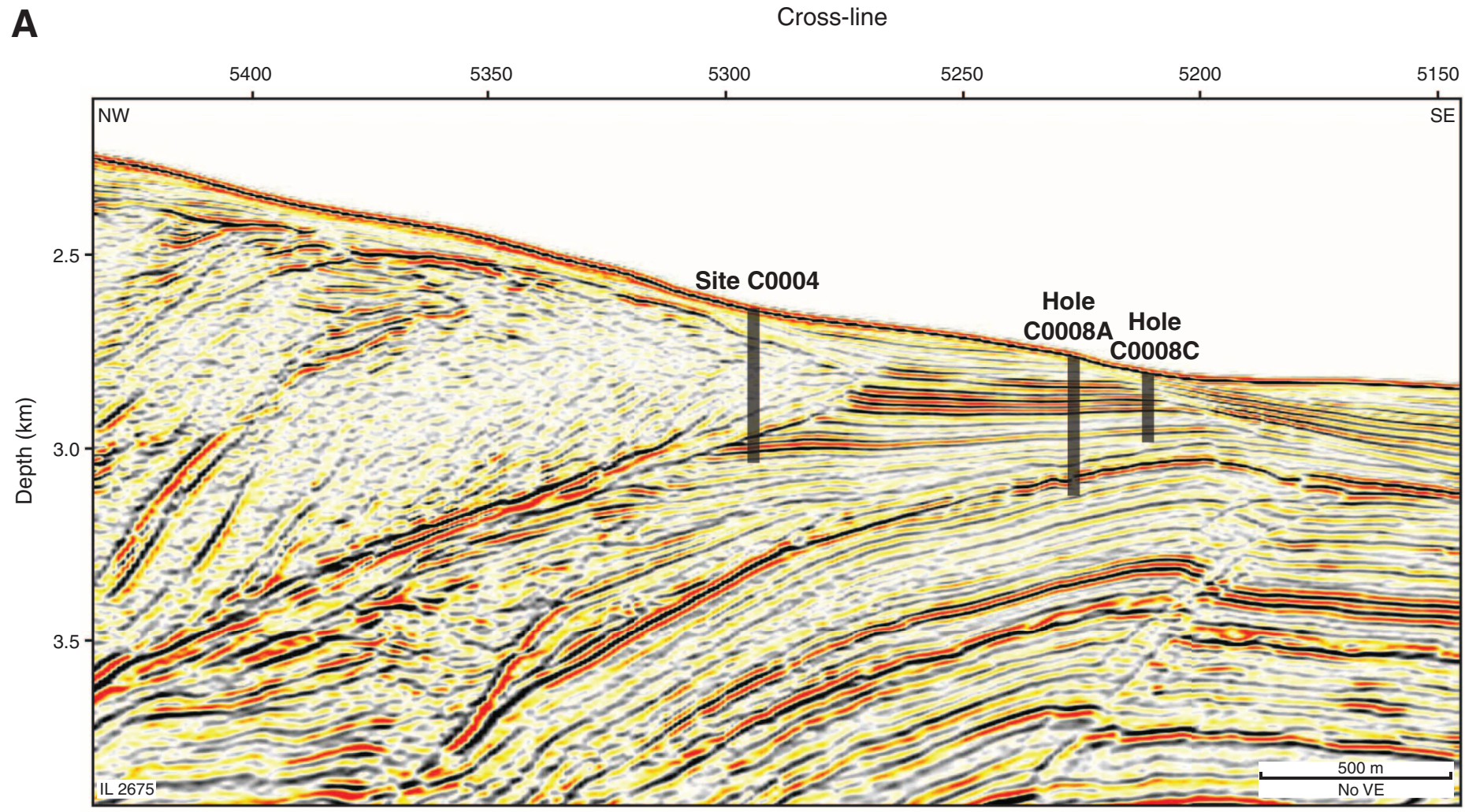




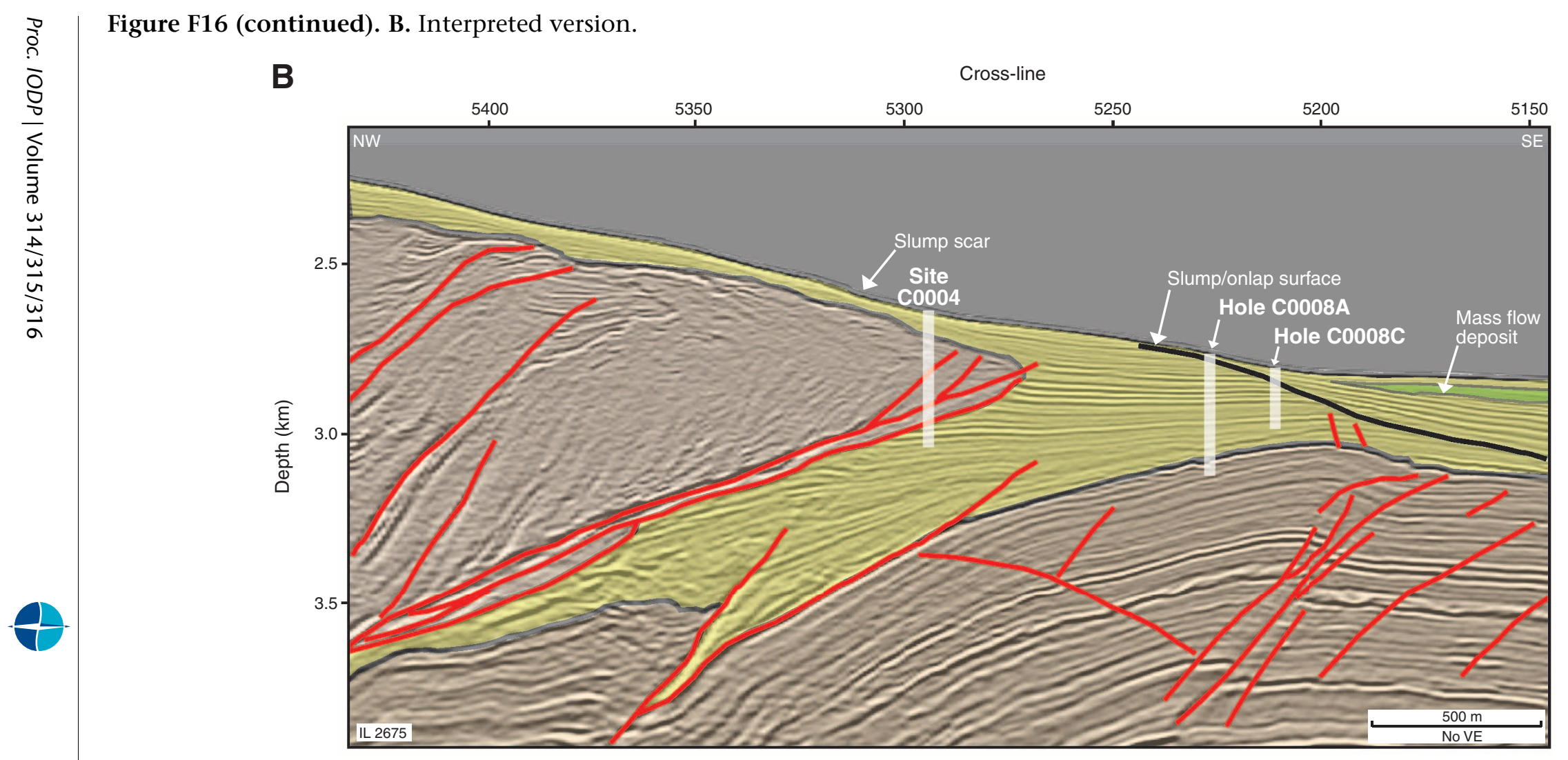


Figure F17. Detail of seismic cross-line (XL) crossing Site C0004 (location shown in Fig. F10). A. Uninterpreted version. VE = vertical exaggeration. (Continued on next page.)

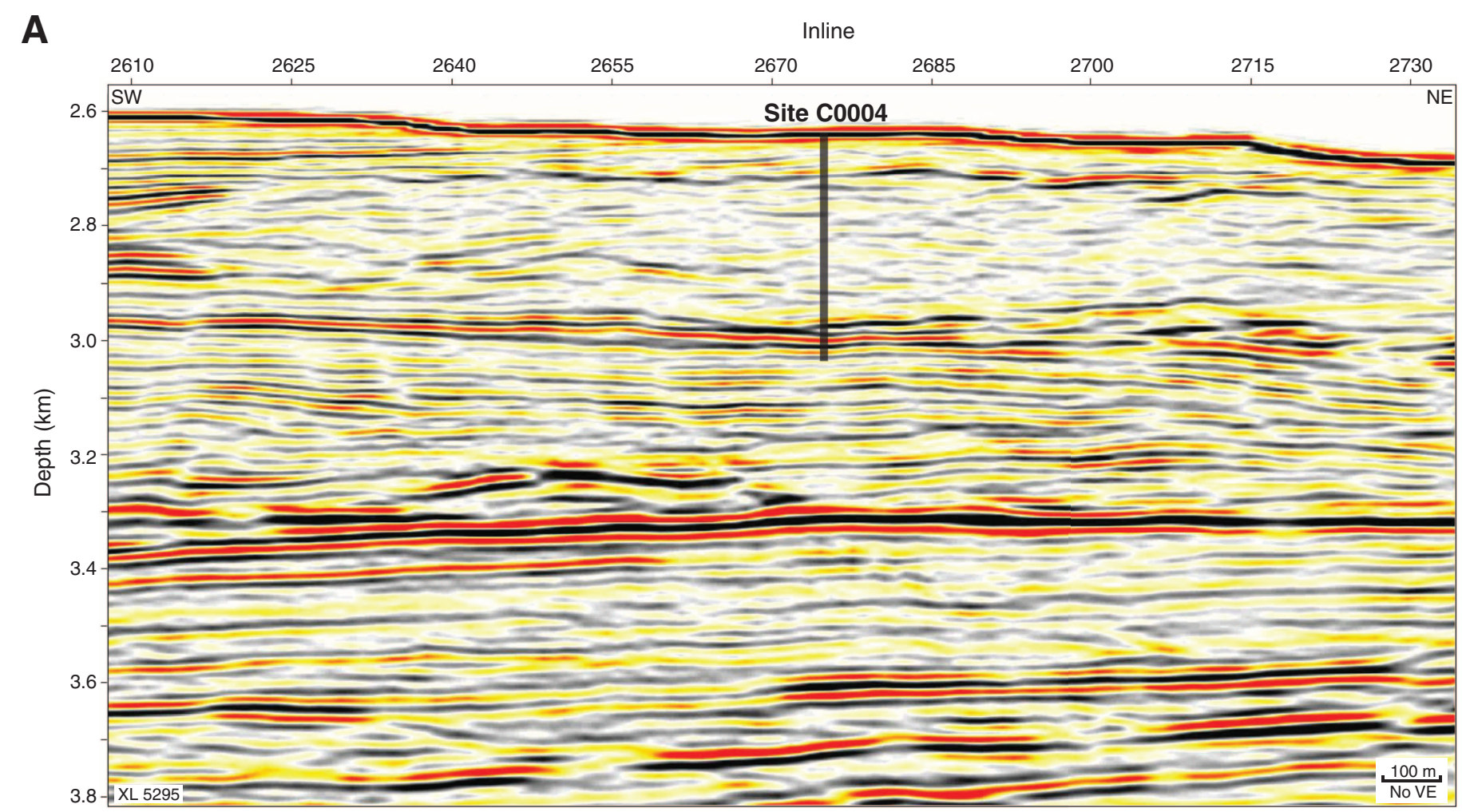




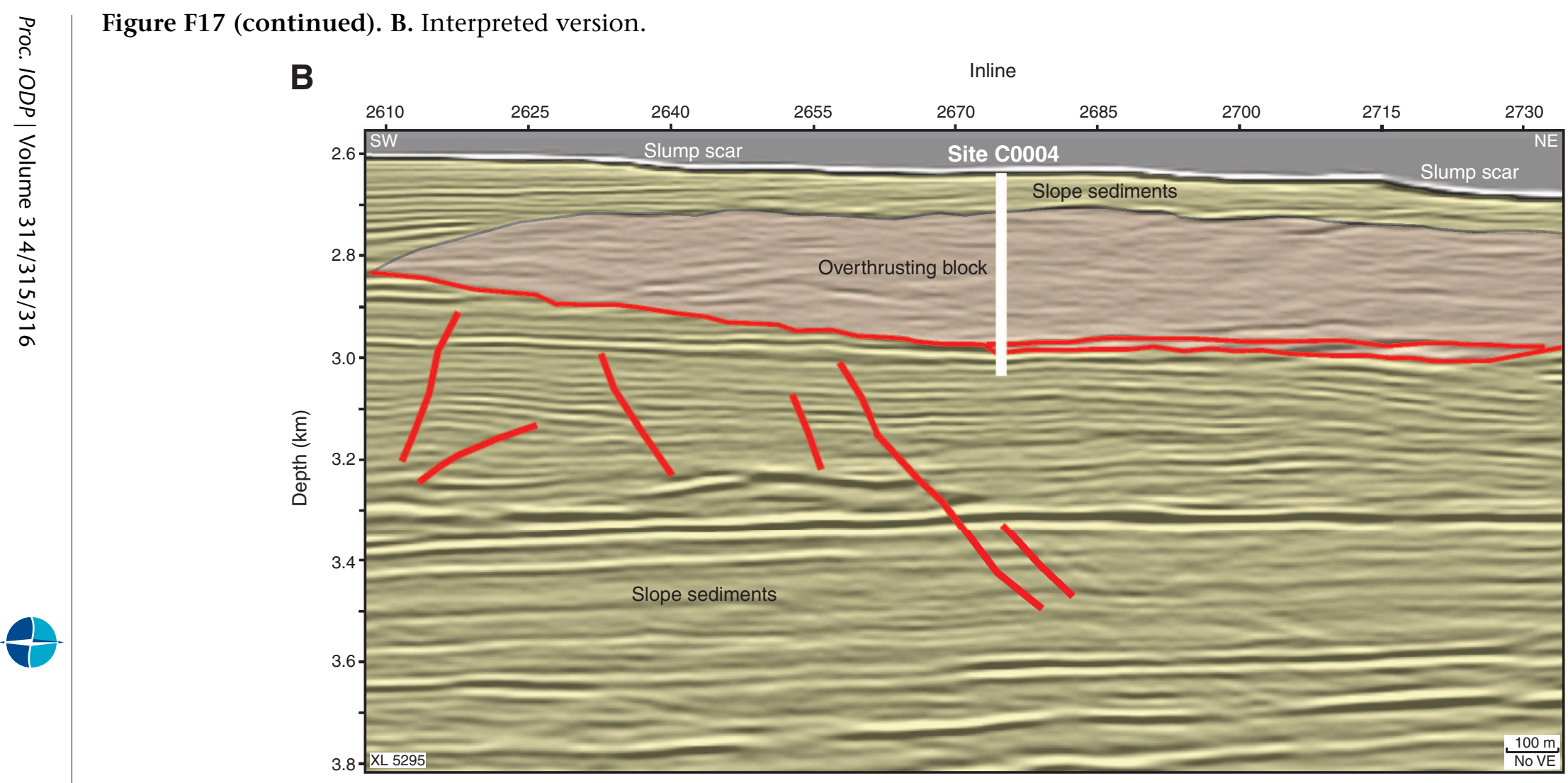


Figure F18. Detail of seismic cross-line (XL) crossing Hole C0008A (location shown in Fig. F10). A. Uninterpreted version. VE $=$ vertical exaggeration. (Continued on next page.)

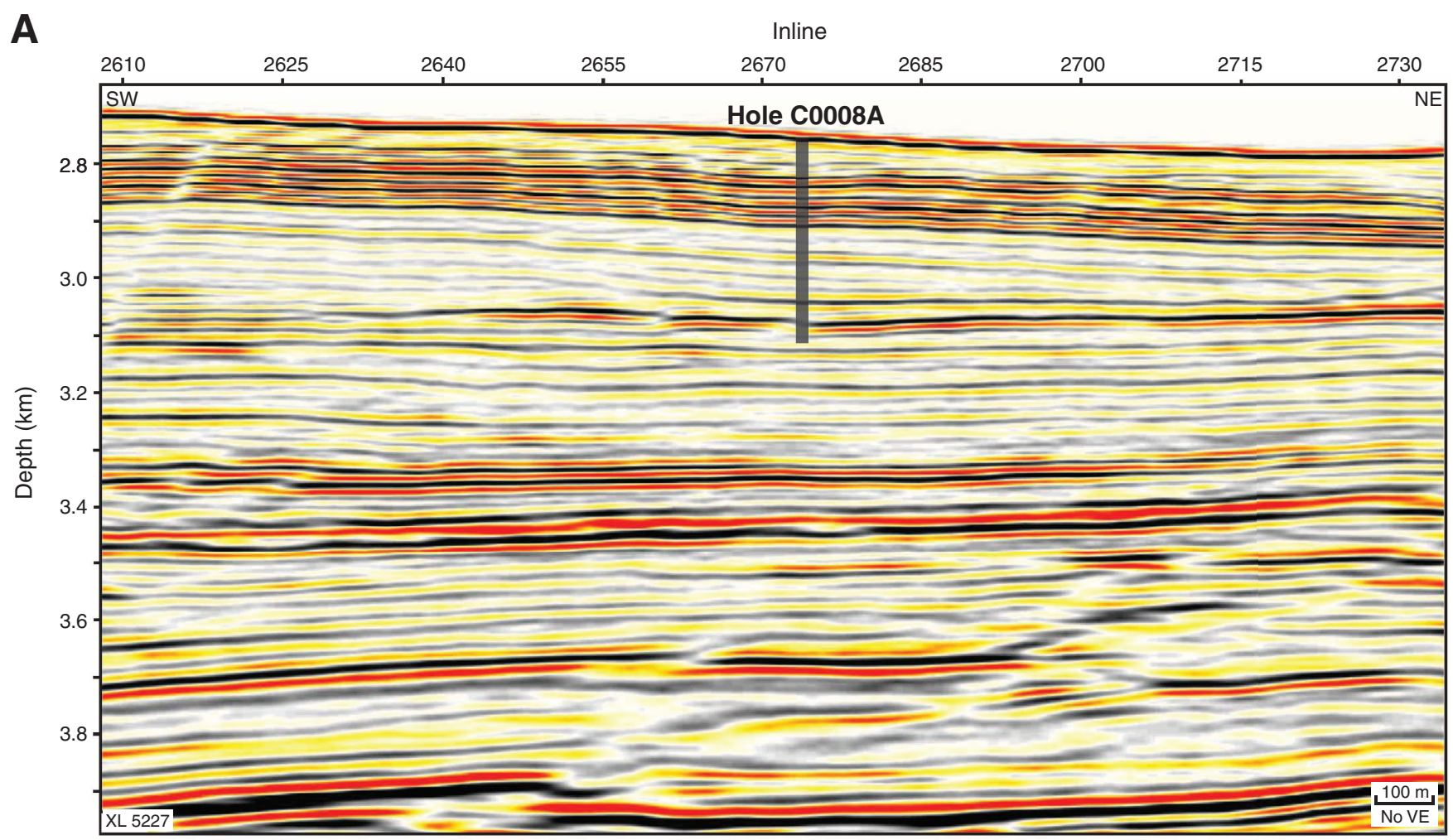




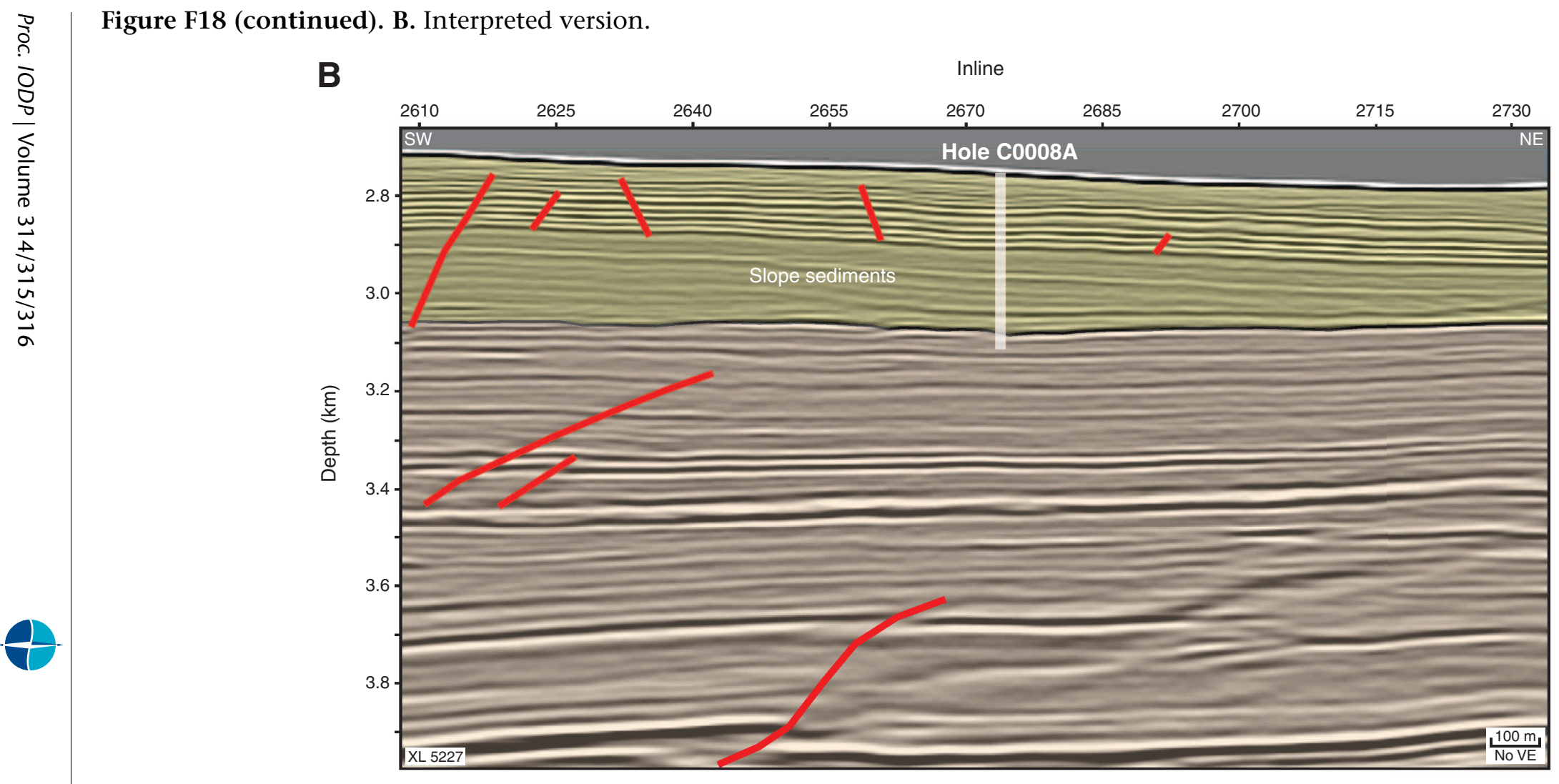


Figure F19. Detail of seismic cross-line (XL) crossing Hole C0008C (location shown in Fig. F10). A. Uninterpreted version. VE $=$ vertical exaggeration. (Continued on next page.)

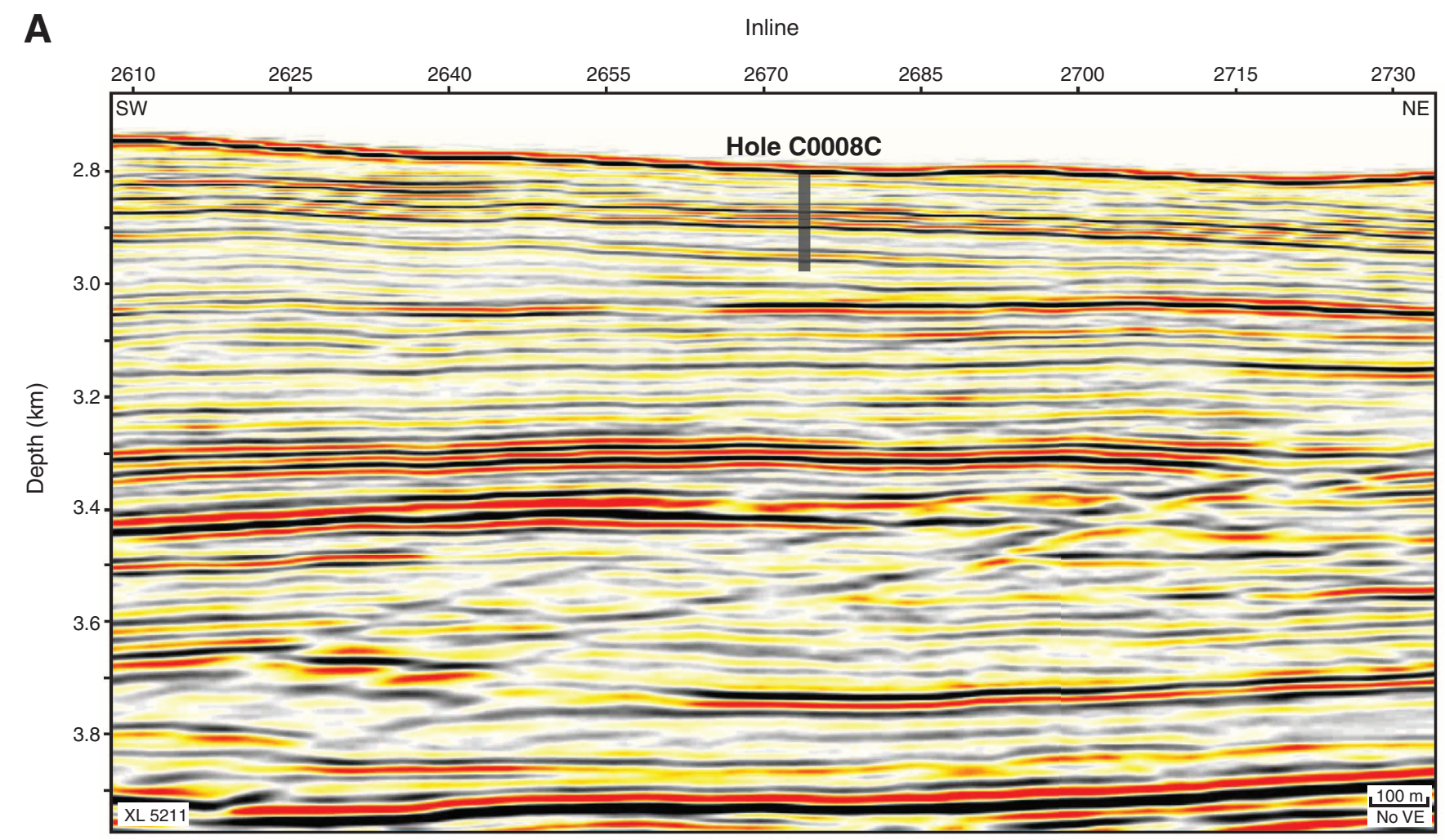




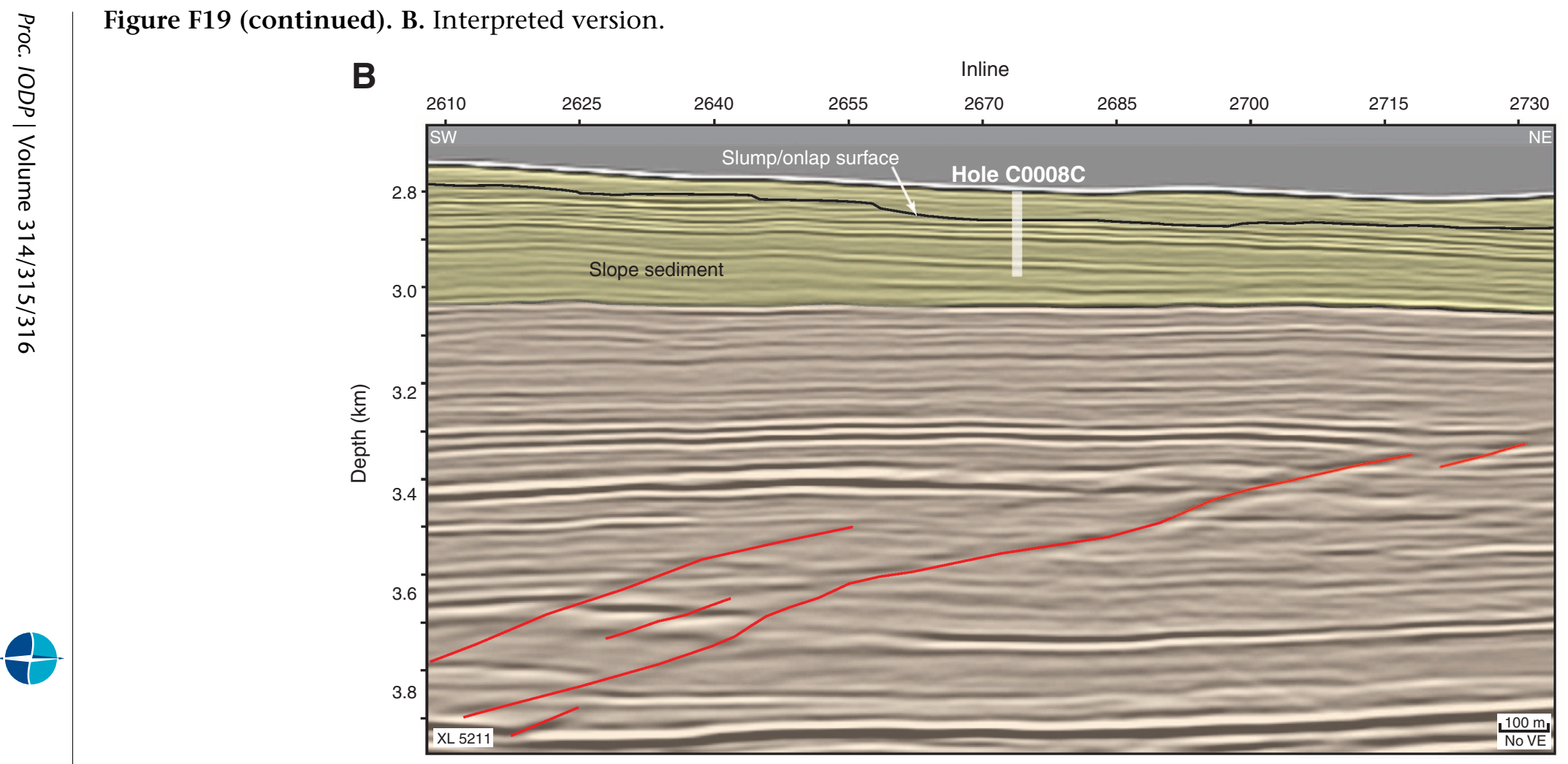


Figure F20. Regional bathymetry, Site C0002. IL = inline, $\mathrm{XL}=$ cross-line.

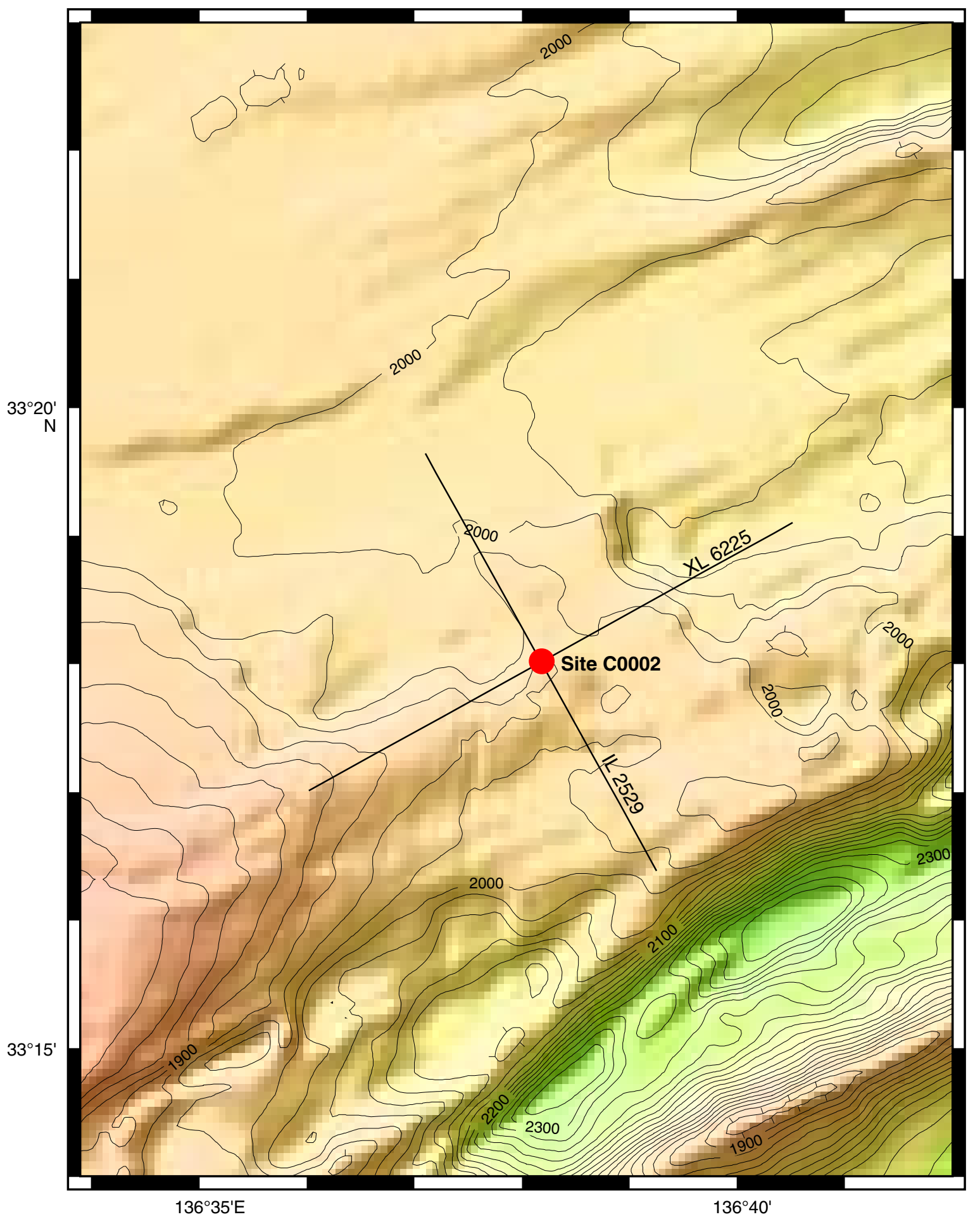


Figure F21. Seismic inline (IL) crossing Site C0002 (location shown in Fig. F20). A. Uninterpreted version. VE = vertical exaggeration. (Continued on next page.)

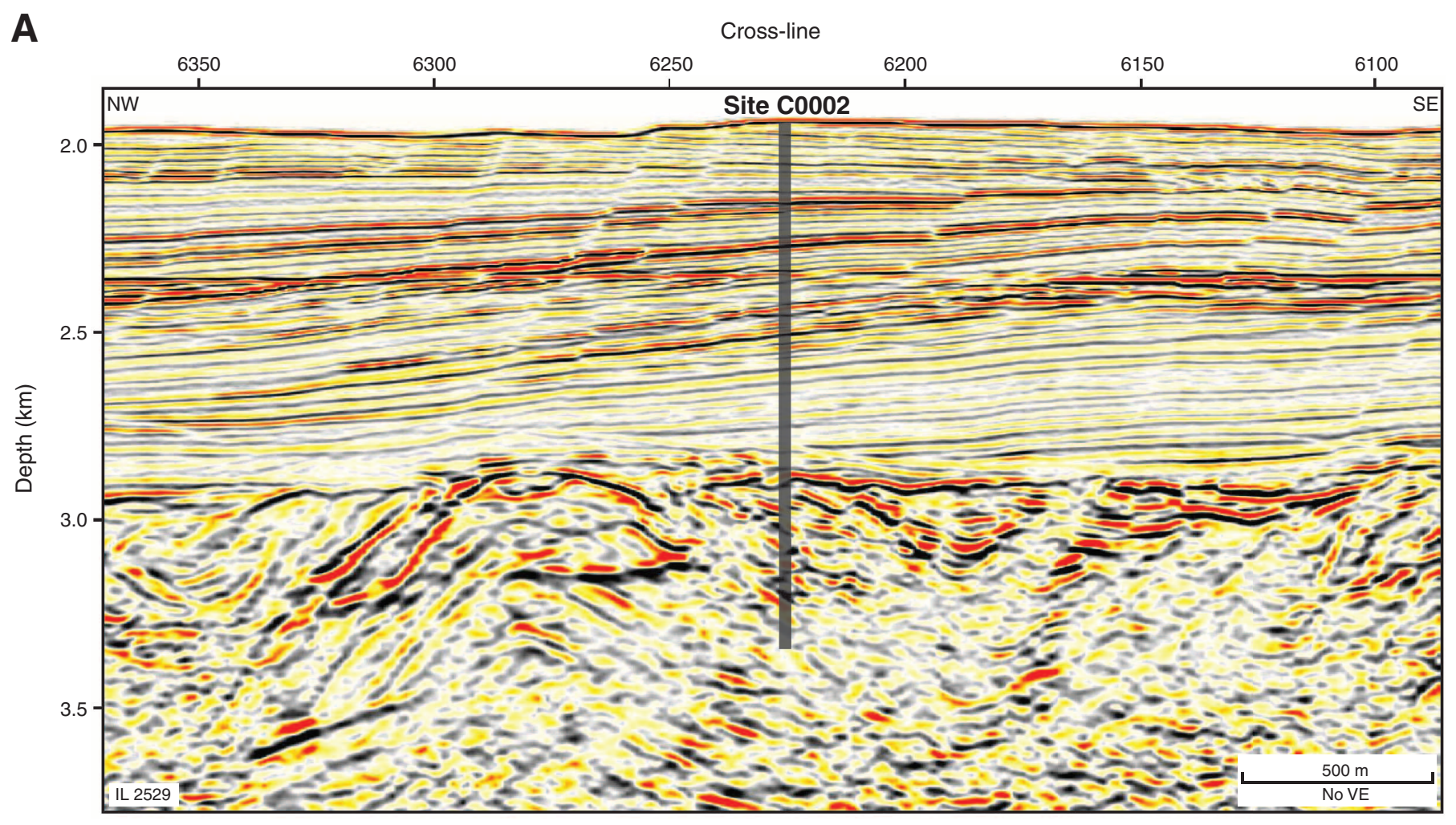




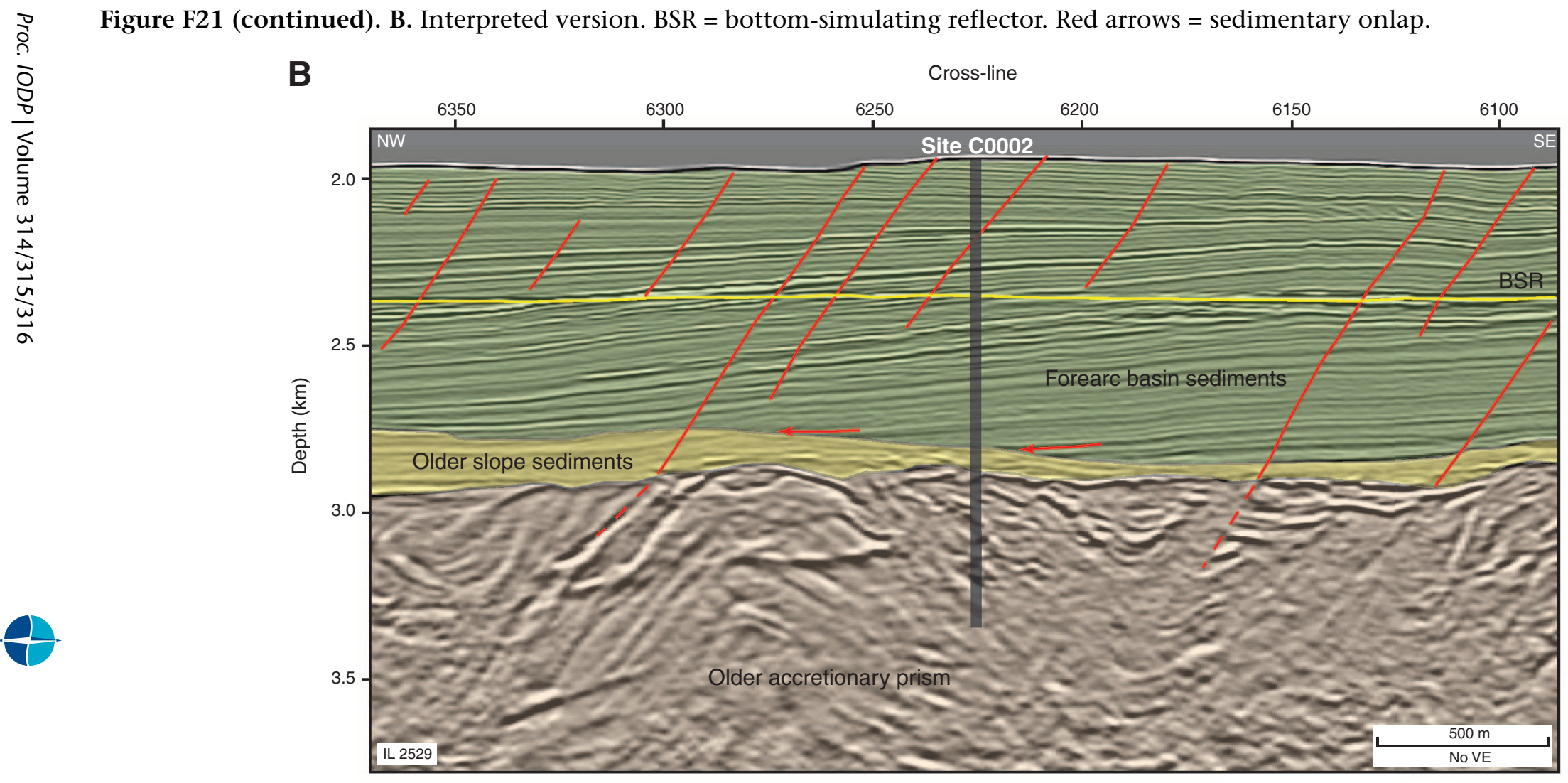


Figure F22. Seismic cross-line (XL) crossing Site C0002 (location shown in Fig. F20). A. Uninterpreted version. VE = vertical exaggeration. (Continued on next page.)

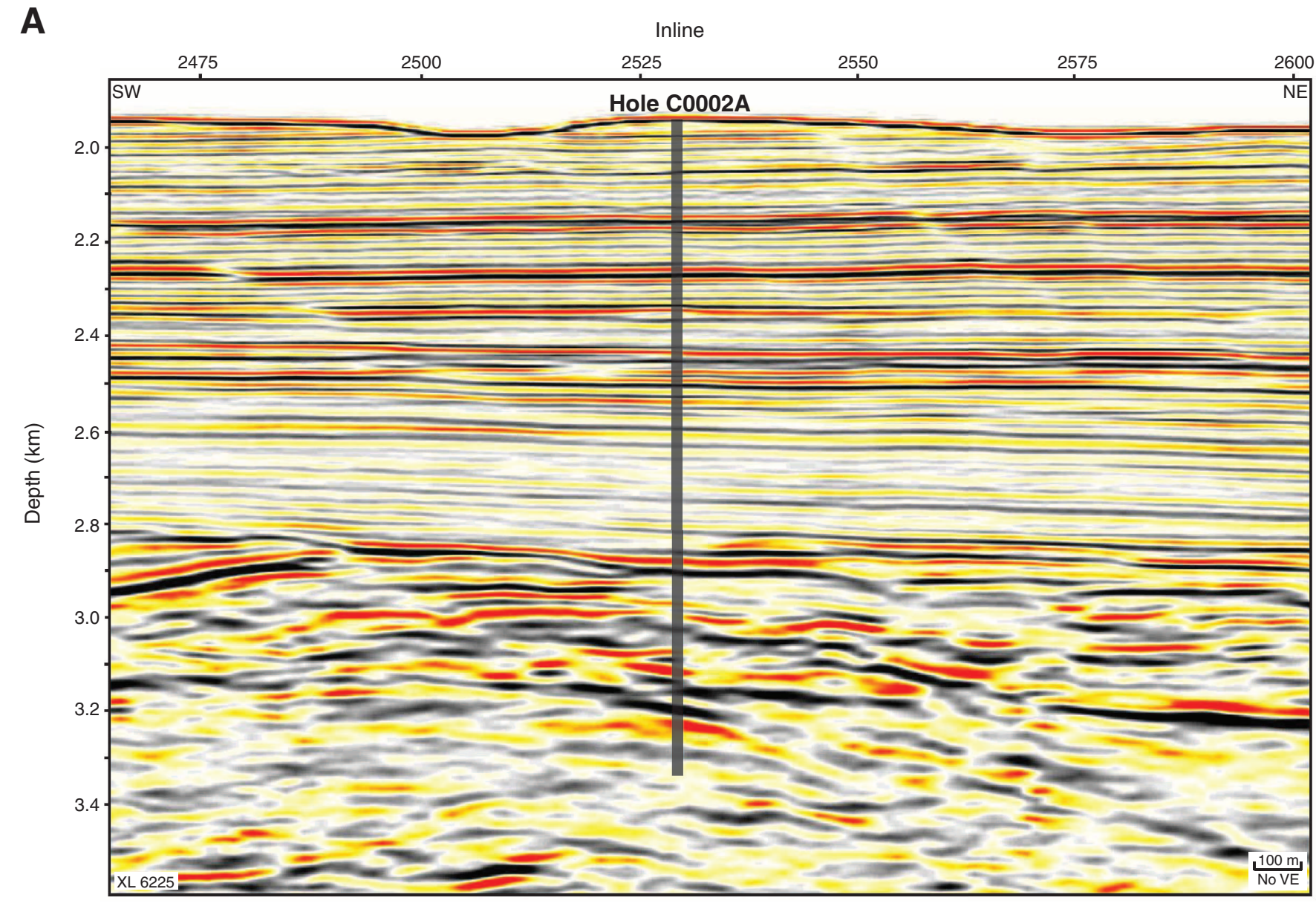




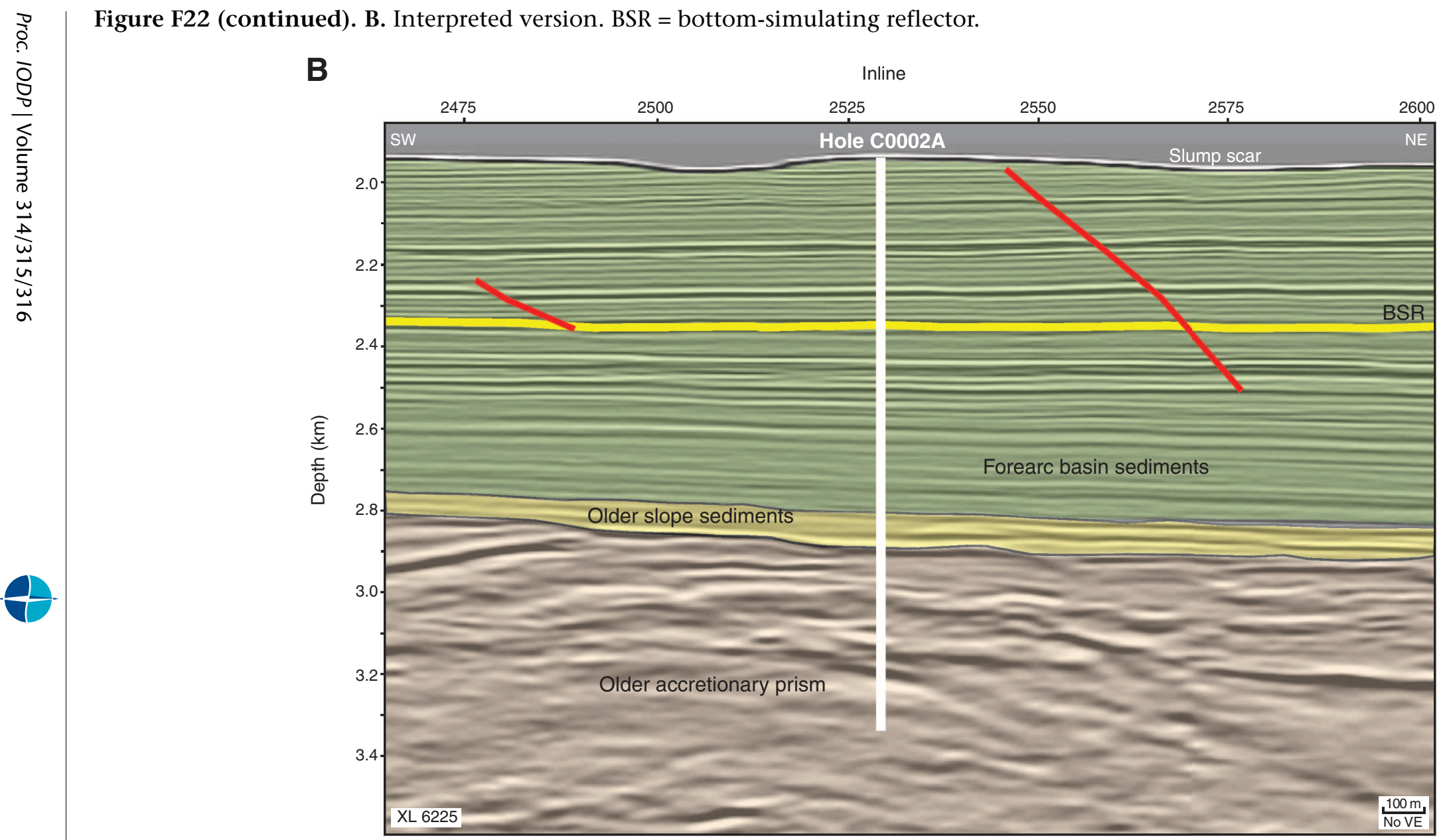




\section{Appendix}

\section{3-D data processing parameters}

\section{Processing by CGG (Kuala Lumpur, Malaysia)}

1. Resample from $2 \mathrm{~ms}$ to $4 \mathrm{~ms}$.

2. Apply low-cut filter $5 \mathrm{~Hz} 18 \mathrm{~dB} /$ Oct.

3. Apply swell noise attenuation.

4. Apply linear noise attenuation using FK filtering.

5. Drop adjacent traces after FK spatial anti-alias filter (receiver interval $=12.5 \mathrm{~m}$ ).

6. First pass velocity analysis $(1 \mathrm{~km} \times 1 \mathrm{~km}$ manual picking).

7. Apply 3-D SRME.

8. Apply minimum phase operator.

9. Apply spherical divergence correction $\mathrm{TV}^{2}$ using first pass velocities.

10. Apply exponential gain correction $1 \mathrm{~dB} / \mathrm{s}$.

11. Second pass velocity analysis $(500 \mathrm{~m} \times 500 \mathrm{~m}$ manual picking).

12. Automatic high-density velocity picking $(100 \mathrm{~m} \times 100 \mathrm{~m})$ with reference velocity from second pass velocity analysis.

13. Shot and channel amplitude correction.

14. 3-D binning $(12.5 \mathrm{~m} \times 37.5 \mathrm{~m}$ bins $)$.

15. Missing trace interpolation.

16. Bin-centering and regularization.

17. 3-D radon demultiple.

18. Diffracted multiple attenuation.

19. F-X cross-line trace interpolation to $18.75 \mathrm{~m}$ bin size.

20. Offset domain multiple attenuation (SPLAT).

21. 3-D anisotropic Kirchhoff prestack time migration (PSTM) with aperture $4 \mathrm{~km}$ in inline and cross-line direction, dip $=90^{\circ}$.

22. High-density automatic velocity and estimated time of arrival (ETA) picking every $50 \mathrm{~m} \times 37.5 \mathrm{~m}$ for residual move-out (RMO).

23. NMO corrected with RMO velocities and ETA values.

24. Outer and inner trace mute.

25. PSTM stack.

26. Poststack multiple attenuation.

27. Dip-dependent median filter.

28. Apply time variant filter to follow water bottom. For $0-1800 \mathrm{~ms}$, frequency should be $0 / 18-90 / 72 \mathrm{~Hz} / \mathrm{dB}$. For 2,000-11,000 ms, frequency should be $0 / 18-50 / 72 \mathrm{~Hz} / \mathrm{dB}$.

29. Apply trace equalization, AGC with operator length $=1000 \mathrm{~ms}$.

\section{Processing by JAMSTEC (Yokohama, Japan)}

21a. PSDM velocity analysis with horizon- and grid-based tomography (31 iterations).

22a. Kirchhoff prestack depth migration (PSDM).

23a. Outer and inner trace mute.

24a. PSDM stack.

25a. Space and depth variant band-pass filter. 